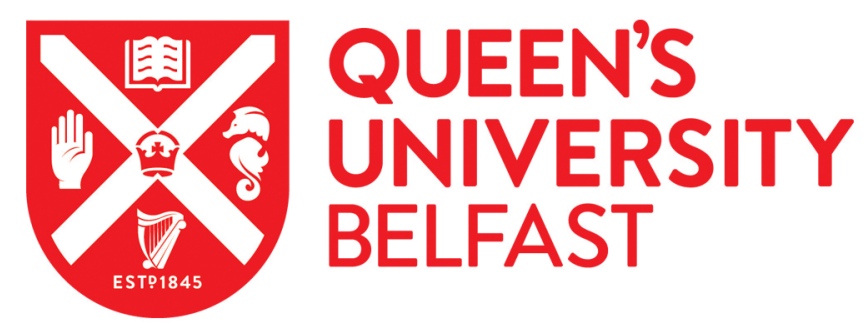

\title{
Compressive behavior of steel fiber reinforced recycled aggregate concrete after exposure to elevated temperatures
}

Chen, G. M., He, Y. H., Yang, H., Chen, J. F., \& Guo, Y. C. (2014). Compressive behavior of steel fiber reinforced recycled aggregate concrete after exposure to elevated temperatures. Construction and Building Materials, 71, 1-15. https://doi.org/10.1016/j.conbuildmat.2014.08.012

Published in:

Construction and Building Materials

Document Version:

Peer reviewed version

Queen's University Belfast - Research Portal:

Link to publication record in Queen's University Belfast Research Portal

Publisher rights

(c) 2014 Elsevier Ltd.

This manuscript version is made available under the CC-BY-NC-ND 4.0 license http://creativecommons.org/licenses/by-nc-nd/4.0/ which permits distribution and reproduction for non-commercial purposes, provided the author and source are cited.

\section{General rights}

Copyright for the publications made accessible via the Queen's University Belfast Research Portal is retained by the author(s) and / or other copyright owners and it is a condition of accessing these publications that users recognise and abide by the legal requirements associated with these rights.

Take down policy

The Research Portal is Queen's institutional repository that provides access to Queen's research output. Every effort has been made to ensure that content in the Research Portal does not infringe any person's rights, or applicable UK laws. If you discover content in the Research Portal that you believe breaches copyright or violates any law, please contact openaccess@qub.ac.uk. 
Compressive behavior of steel fiber reinforced recycled aggregate concrete after exposure to elevated temperatures

\author{
G.M. Chen ${ }^{\mathrm{a}}$, Y.H. He ${ }^{\mathrm{a}}$, H. Yang ${ }^{\mathrm{a}}$, J.F. Chen ${ }^{\mathrm{a}, \mathrm{b},{ }^{*}}$ and Y.C. Guo ${ }^{\mathrm{a}}$ \\ a School of Civil and Transportation Engineering, Guangdong University of Technology, \\ Guangzhou 510006, China \\ ${ }^{\mathrm{b}}$ School of Planning, Architecture and Civil Engineering, Queen's University Belfast, UK.
}

\begin{abstract}
For sustainability considerations, the use of recycled aggregate in concrete has attracted many interests in the research community. One of the main concerns for using such concrete in buildings is its spalling in fire. This may be alleviated by adding steel fibers to form steel fiber reinforced recycled aggregate concrete (SFRAC). This paper presents an experimental investigation into the compressive properties of SFRAC cylinders after exposure to elevated temperatures, including the compressive strength, Young's modulus (stiffness), stress-strain curve and energy absorption capacity (toughness). The effects of two parameters, namely steel fiber volume content $(0 \%, 0.5 \%, 1 \%, 1.5 \%)$ and temperature (room temperature, $200^{\circ} \mathrm{C}$, $400^{\circ} \mathrm{C}$ and $600^{\circ} \mathrm{C}$ ) on the compressive mechanical properties of concrete were investigated. The test results show that both compressive strength and stiffness of the concrete are significantly reduced after exposure to high temperatures. The addition of steel fibers is helpful in preventing spalling, and significantly improves the ductility and the cracking behavior of recycled aggregate concrete (RAC) after exposure to high temperatures, which is favorable for the application of RAC in building construction.
\end{abstract}

Keywords: Steel fiber; recycled aggregate concrete; elevated temperature; compressive behavior; stress-strain relationship

\footnotetext{
* Corresponding author. Tel.: +44 289097 4184; fax: +4428 9097 4278;

E-mail address: J.Chen@qub.ac.uk (J.F. Chen)
} 


\section{Introduction}

In recent years, the reuse of waste concrete as recycled concrete aggregates (RCA) to either partially or totally replace natural aggregates for new concrete has emerged as a commercially viable and technically feasible technique for recycling waste concrete [1]. A concrete using RCA as coarse aggregate is termed recycled aggregate concrete [2] and will be referred to as RAC for simplicity in this study. The recycling of waste concrete has significant environmental benefits such as sustainable utilization of natural resources and saving landfill spaces, leading to an increasing amount of research recently [3-5]. Existing studies have covered a number of topics, such as mechanical properties and durability of RAC [6-7] and structural performance of members cast with RAC [8], mix designs of both normal strength RAC [9] and high performance RAC [10]. Compared to natural aggregate concrete (referred to as NC hereafter), RAC has lower specific gravity, lower strength and stiffness, larger creep and shrinkage [11]. Moreover, the replacement percentage (referred to as RP hereafter) of RCA, which is usually defined as the ratio between the mass of recycled aggregate to the total mass of coarse aggregate, has been found to have a considerable influence on the stress-strain curve of RAC [7]. It has been shown that for RP ranging from $0 \%$ to $100 \%$, the RAC shows an increase in the strain at peak stress and a significant decrease in ductility as characterized by their descending branch of the stress-strain curve, compressive strength and elastic modulus when RP increases. Xiao et al. [4] also observed that the RCA has an adverse effect on the shear transfer strength of RAC especially when the RP is over $30 \%$. As a result, the RAC has been used mainly in non-structural concretes (e.g. pavements [5]).

The use of RAC in structural members is limited [12]. To explore potential applications of RAC in structural members, various methods have been attempted to mitigate the disadvantages of RAC such as lower strength and reduced durability. Kou and Poon [13] reported that the negative effect of RCA on durability can be mitigated by incorporating a certain amount of mineral admixture, such as fly ash and volcanic ash. It was also shown that the use of glass fiber reinforced plastic (GFRP) or steel to confine RAC is an effective way to eliminate these weaknesses [14-15], making it possible to use RCA in structural members. In 
the mainland China, successful applications of RAC in the building construction (mainly as foundations and walls) started in 2004 [12].

Since the invention of steel fibers reinforced concrete (SFRC) in 1874 [16], it has become a useful structural material since 1970s [17], mainly because the addition of steel fibers significantly improves the mechanical properties of concrete, including impact strength, toughness, flexural strength, tensile strength, ductility and the ability to resist cracking and spalling [18]. Although SFRC has been increasingly used in structures, such as floors of building, precast members, tunnels, heavy duty pavement and mining structures [19], it is still a material subject to extensive investigation [20-21]. The aspect ratio $l / d$ and volume fraction $V_{\mathrm{f}}$ of steel fibers can significantly affect the workability of SFRC [22]. Generally, the aspect ratio is between 50 and 100: the probability of heterogeneous distribution and flocculation of fibers in a concrete mix is increased when $l / d$ increases. The most suitable volume fraction is between $0.5 \%$ and $2.5 \%$ by volume [22].

Steel fibers may be added to RAC to improve its properties, making it suitable for use in building constructions. It is well known that the use of RCA in mortar and concrete increases shrinkage because the RCA can absorb a large quantity of water [5, 23]. Adding fibers into concrete and mortar is an effective method to reduce shrinkage and associated cracking. When the steel fiber content is greater than $0.25 \%$, the crack width of the steel fiber reinforced recycled aggregate concrete (SFRAC) can be considerably reduced [23]. The addition of steel fibers can also significantly increase the post-peak stress and the energy absorption capacity of RAC [24].

Fire represents one of the major risks to building structures. Fire can cause explosive spalling [25] and mechanical deterioration of concrete [26]. A number of measures [27-29] have been explored to alleviate the adverse effects of high temperatures. It has been well established that the inclusion of polypropylene fiber or steel fibers can enhance the mechanical properties (e.g. residual strength, residual fracture energy, spalling resistance and toughness) of normal concrete after exposure to fire or high temperatures [30-31]. For RAC, limited studies [32-35] 
have shown that after exposure to high temperatures, its strength is apparently reduced, and the higher the exposure temperatures [36], the longer the exposure time at high temperature [32], the larger the strength decrease. The residual strength of RAC is shown to be superior [32-34] or comparable [35] to that of conventional concrete.

It is generally believed that strength deterioration mechanism of concrete subjected to high temperature is related to two main factors [30]: 1) the increase of vapour pressure arising from the evaporation of moisture; and 2) the initiation and development of cracks caused by thermal stresses due to temperature difference between different parts (e.g. surface and core) of concrete. As the moisture contents and the constituent materials of aggregates (and thus the interface between aggregates and mortar) are quite different between $\mathrm{NC}$ and RAC, the effects of these two factors should be different for RAC and NC. Consequently, the performance of RAC during and after exposure to high temperature has been recognized as a significant area requiring extensive further research [37]. A number of measures such as addition of fibers [38] and pozzolan [39], and post-fire-recuring of fire damaged concrete [29] have been shown to effectively alleviate the adverse effects of fire/high temperature for NC. The effectiveness of these measures for RAC is yet to be investigated.

Against the above background, this paper presents an experimental study on the compressive properties, including residual strength, Young's modulus, stress-strain relationship and energy dissipation capacity, of SFRAC after exposure to elevated temperatures. This study constitutes a part of a series of ongoing studies aiming to explore effective measures to alleviate the adverse effect of fire/high temperature on RAC. The results presented in this paper are valuable for achieving a better understanding of the role of steel fibers in the performance of RAC after exposure to high temperatures, and should be helpful to expand the application of RAC in structures, especially in building structures.

\section{Experimental programme}

A total of 5 groups of specimens, each consisting of 12 standard cylinders with a dimension of 
$150 \mathrm{~mm} \times 300 \mathrm{~mm}$ (diameter and height), were prepared and tested in this study. The basic properties of the constituent materials, their mix proportions, specimen preparation procedure and loading scheme are described in the following sections.

\subsection{Constituent materials}

The constituent materials include:

- ordinary Portland cement with a strength of $42.5 \mathrm{MPa}$ according to the data sheet provided by the material supplier;

- naturally sourced medium-coarse river sand with an apparent density of $2580 \mathrm{~kg} / \mathrm{m}^{3}$, a fineness modulus of 2.52 and a moisture content of $0.8 \%$ (by weight);

- limestone natural coarse aggregate (NCA) with a maximum particle size of $30 \mathrm{~mm}$;

- recycled concrete coarse aggregate originated from crushed waste concrete, with size ranging from 4 to $30 \mathrm{~mm}$. The weight ratio between fine recycled coarse aggregate (FRCA, with sizes in the range between $4 \mathrm{~mm}$ and $8.5 \mathrm{~mm}$ ) and coarse recycled coarse aggregate (CRCA, with sizes in the range of $10 \mathrm{~mm}$ and $30 \mathrm{~mm}$ ) was $3: 2$ following Xiao [40];

- corrugated steel fibers (with rectangular cross-section) made from ordinary steel with a melting temperature of about $1500^{\circ} \mathrm{C}$ and a density of $7.85 \mathrm{~g} / \mathrm{cm}^{3}$. The fibres had a length of $32 \mathrm{~mm}$, an aspect ratio of 40 and a tensile strength of $600 \mathrm{MPa}$;

- naphthalene-based high efficiency water-reducing admixture with a solid content of $30 \%$ and a water reducing rate of $20 \%$.

The water absorption capacities of the natural and recycled coarse aggregates were tested as $0.76 \%$ and $3.08 \%$, respectively. The concrete aggregates and steel fibers are shown in Fig. 1.

\subsection{Mix proportioning}

A total of 5 concrete mixes were designed and prepared to study the effect of steel fiber content on the axial compressive behavior of RAC after exposure to elevated temperatures 
$\left(25^{\circ} \mathrm{C}, 200^{\circ} \mathrm{C}, 400^{\circ} \mathrm{C}\right.$ and $\left.600^{\circ} \mathrm{C}\right)$. The natural coarse aggregate was used in the first mix; while in the remaining 4 mixes recycled concrete aggregates were used to fully replace the natural coarse aggregates by volume. The 5 concrete mixes had the same free water-to-cement ratio of 0.46 . An additional $3.08 \%$ water by weight of RCA was added to the four RAC mixes to cater for the large water absorption capacity of RCA. Three of the RAC mixes included respectively $0.5 \%, 1 \%, 1.5 \%$ steel fibers by volume. Details of the mixes are summarized in Table 1 in which the concrete mix with natural aggregate is termed as $\mathrm{NC}$, and that with RCA is termed as RAC. When steel fibers are included in the mix, the mix is labeled as SFRACx, with " $\mathrm{x}$ " representing the percentage ratio of steel fiber by volume, e.g., SFRAC5 representing $0.5 \%$ steel fibers for the SFRAC.

\subsection{Specimen preparation}

The concrete were mixed in a concrete mixer. For each of the mixes, 12 standard cylinders of $150 \mathrm{~mm}$ in diameter and $300 \mathrm{~mm}$ in height were cast using plastic molds. Concrete cylinders of the same mix were cast from the same batch to ensure uniformity. The procedure of preparing the concrete mixture was as follows [41]: coarse aggregates, sand, cement and steel fibers were placed in the mixer. The mixer was then started to mix them for 3 minutes before water and super-plasticizer were added. The mixer was then run for further 2 minutes to produce the fresh concrete with evenly dispersed steel fibres [43]. Workability was measured using concrete slump test according to GB/T 50080-2002 [42]. Cast concrete specimens were covered with plastic sheets and kept in the laboratory at room temperature for 24 hours before demolding. After demolding, the specimens were immersed in water for curing until the age of 28 days, and then kept in the Materials Lab at Guangdong University of Technology at the ambient temperature of about $25^{\circ} \mathrm{C}$ until testing .

\subsection{Test method}

\subsubsection{Heating scheme}

The specimens were heated in an electrical furnace following the following heating scheme: 
- Heating rate: a constant rate of $2.5^{\circ} \mathrm{C} / \mathrm{min}$ following Poon et al. [27] until the target temperature is reached. It should be noted that this heating rate is much lower than that of the standard ISO 834 curve [44], but this is not critical if only the core of columns (i.e. inside the spirals or hoop ties) is concerned. The behavior of the concrete cover under a rapidly developing fire can be different but this is beyond the scope of this paper. Within the core concrete the heating rates and peak temperatures experienced would be moderated by the thermal protection of the cover concrete. It should also be noted that the standard fire does not necessarily reflect the actual heating of concrete within a real structure during a real fire [45];

- Soaking period: 1 hour, following previous research such as Poon et al. [27], Peng et al. [30], Cavdar et al. [46] and Husem et al. [47]. Although it had been speculated shown that one hour of soaking is sufficient for the heated specimens with size similar to the specimens of this study to reach a uniform temperature distribution [30], a more recent study [45] showed that this is not necessarily the case. The temperature distribution in a specimen, especially in a large one, is likely to be non-uniform for a long period. As the residual properties of a concrete depend on the temperature history (including the heating rate, the peak temperature, soaking time and cooling regime), the behavior of concrete from different parts of the specimen would also be different. Therefore, test results may only be comparable if the specimens have the same size and subjected to the same heating and cooling regimes;

- Cooling rate (cooling curve): after the soaking, the furnace was switched off but was kept in closed condition for $1 \mathrm{~h}$ before its door was opened for the specimens to be further cooled to room temperature as in [48]. The furnace temperature was recorded every half an hour for four hours during the cooling period, giving eight readings (Fig. 2);

- Spalling prevention measures: in previous studies (Peng et al. [30]; Rahim et al. [48]; and Zheng et al. [49]) specimens were usually heated in the furnace at $105^{\circ} \mathrm{C}$ or $120^{\circ} \mathrm{C}$ for $24 \mathrm{~h}$ or $48 \mathrm{~h}$ to prevent spalling due to excessive moisture emission during the heating process. In this study, when one batch of specimens were under heating, the next batch of specimens were put outside the furnace for pre-heating, which 
usually lasted for 6-9 hours depending on the target temperature. This treatment, together with the adopted lower rate of heating $\left(2.5^{\circ} \mathrm{C} / \mathrm{min}\right)$, successfully prevented explosive spalling during heating.

Among the 12 cylinder specimens in each mix, three were tested immediately after curing for about 3 months, the remaining 9 specimens were divided into three groups, subjected to respectively $200^{\circ} \mathrm{C}, 400^{\circ} \mathrm{C}$ and $600^{\circ} \mathrm{C}$ exposure in the electrical furnace following the above heating procedure, and then tested. Fig. 2 shows the temperature-time curves recorded during heating. All specimens were weighted before and after the heat treatment. After exposure to high temperature, all specimens were inspected for the surface changes including colour and cracks etc.

\subsubsection{Compression test}

Both the upper and lower surfaces of each cylinder specimen were capped levelly with gypsum plaster which had a compressive strength of $800 \mathrm{MPa}$. All specimens were tested for compression strength under a constant displacement rate of $0.18 \mathrm{~mm} / \mathrm{min}$ following ASTM C39/C39M [50] using a $4000 \mathrm{kN}$ MATEST compression machine (Fig. 3(a)). For each specimen, two $100 \mathrm{~mm}$ strain gauges were placed at $180^{\circ}$ apart at the mid-height to measure the axial strains, and two $80 \mathrm{~mm}$ strain gauges were placed at $180^{\circ}$ apart to measure the hoop strains also at the mid-height. In addition, the axial strains were also measured by two linear variable displacement transducers (LVDT) at $180^{\circ}$ apart, covering the mid-height region of $120 \mathrm{~mm}$ for all specimens as in [51], (Fig. 3(b)).

\section{Test results and discussions}

In this section, the effects of elevated temperature and steel fiber content on the compressive behaviour, including failure mode, residual strength, Young's modulus (stiffness), and energy absorption capacity (ductility) were analyzed based on the test data obtained from the compression tests. Visual inspection and mass loss test results were also discussed. 


\subsection{Visual inspection of concrete specimens}

\subsubsection{Color changes}

Fig. 4 shows the color changes of concrete mixes after exposure to elevated temperatures. At room temperature, the surface of concrete was usually light grey, which was turned to yellowish, gray brown and gray white after exposure to $200{ }^{\circ} \mathrm{C}, 400{ }^{\circ} \mathrm{C}$ and $600{ }^{\circ} \mathrm{C}$, respectively. It has been shown that the color change in the specimens is associated with the chemical and physical changes experienced by the concrete after exposure to high temperatures $[31,52-53]$.

\subsubsection{Spalling}

Explosive spalling was not observed for all the concrete specimens during the process of heating even though explosive spalling under high temperature has been widely observed in concrete especially for high strength concrete [30-31]. The absence of spalling in present study might be a result of slower rate of heating (at $2.5^{\circ} \mathrm{C} / \mathrm{min}$ ) adopted in the present study. A trial test conducted in the early stage of this study found that higher rate (e.g. $\left.7^{\circ} \mathrm{C} / \mathrm{min}\right)$ led to explosive spalling for both $\mathrm{NC}$ and RAC during heating. For RAC, the compatibility of thermal expansion between RCA and surrounding cement paste [32], and the beneficial effects of steel fibers $[27,53]$ might have also played a significant role for the absence of explosive spalling failure.

\subsubsection{Cracking behavior}

For normal concrete (without steel fibers) after exposure to evaluated temperatures, stresses within and between the concrete constituents (cement paste and aggregate) caused by water vapor pressure, thermal stresses due to temperature difference between different parts (e.g. surface and core) of the concrete and their interaction account for the initiation and development of cracking [54]; these factors also account for the cracking of RAC (with and without steel fibers) subjected to high temperature. In the present study, no crack was observed by naked eyes on concrete specimens after exposure to $200^{\circ} \mathrm{C}$; a few of hairline 
cracks could be identified by naked eyes for specimens after exposure to the high temperature of $400^{\circ} \mathrm{C}$ and $600^{\circ} \mathrm{C}$. For concrete specimens without steel fiber (Specimens NC and RAC), an increasing number of wider and deeper cracks were observed on the surfaces of the specimens with the increasing of exposure temperature, regardless whether the recycled concrete aggregates were used or not, as shown in Fig. 4. The maximum crack widths (Figs 5-6) were measured using a crack width gauge which had an accuracy of $0.01 \mathrm{~mm}$ and listed in Table 2. It should be noted that the crack width measurement had been carried out at a number of locations for each of the three specimens with the same concrete mix. Figs. 5-6 showed the maximum measured crack widths (the same with those listed in Table 2).

Figs. 5-6 show that the crack width for NC and RAC after exposure to high temperatures is close to each other, suggesting that the cracking behavior for $\mathrm{NC}$ and $\mathrm{RAC}$ after exposure to high temperature is similar. Fig. 7 depicts the trend of maximum crack width vs. steel fiber content. It should be noted that the maximum crack width for each point in Fig. 7 represents the average value of three cylinders in the group. The same is followed in presenting the test results in the remainder of this paper unless otherwise stated. Also shown in Fig. 7 are error bars standing for the double-side standard deviation intervals for the average maximum crack width values. Fig. 7 shows clearly that the inclusion of steel fibers in RAC significantly restrains the development of cracks caused by the exposure to high temperatures due to the so-called bridging effect of fibers, as in normal concrete [55]. For the RAC specimens (RAC, SFRAC5, SFRAC10 and SFRAC15), when the steel fiber content increases from zero (specimen RAC) to $1.5 \%$ (specimen SFRAC15), the average of the maximum crack width decreased from $0.23 \mathrm{~mm}$ to $0.07 \mathrm{~mm}$ and from $0.72 \mathrm{~mm}$ to $0.15 \mathrm{~mm}$ for the target exposure temperature of $400^{\circ} \mathrm{C}$ and $600^{\circ} \mathrm{C}$, respectively (see also Table 2).

\subsection{Mass loss}

The mass loss ratio due to the exposure to elevated temperature, which is defined as the lost mass divided by the original mass, is shown in Fig. 8 for the different concrete mixes.

From Fig. 8(a), it is clear that the mass loss increases with the increase of target temperature 
for all the concrete mixes. The average mass loss ratio is $6.62 \%, 8.77 \%$ and $10.23 \%$ for RAC specimens (specimens RAC + SFRACx in Fig. 8) at temperatures of $200^{\circ} \mathrm{C}, 400^{\circ} \mathrm{C}$ and $600^{\circ} \mathrm{C}$ respectively. Most of the mass loss occurs when the temperature rises from room temperature to $200^{\circ} \mathrm{C}$. The loss increased almost linearly with the exposure temperature after that. This is mainly because water evaporation, the main cause of mass loss of concrete specimens during the heating process, occurs between $25{ }^{\circ} \mathrm{C}-200{ }^{\circ} \mathrm{C}$. Concrete contains capillary water, physically absorbed water (gel water) and chemically bound water (crystal water) in calcium silicate hydrate $(\mathrm{C}-\mathrm{S}-\mathrm{H})$ and calcium hydroxide $\left(\mathrm{Ca}(\mathrm{OH})_{2}\right)$ [56], among which capillary water and physically absorbed water take up a large proportion of cement paste weight and can be driven out of concrete by evaporation when the ambient temperature reaches $200^{\circ} \mathrm{C}$ or above [57]. The chemically bound water is part of cement hydrate compounds and often called non-evaporable water for it cannot be released from cement paste until the chemical decomposition of either $\mathrm{Ca}(\mathrm{OH})_{2}$ and C-S-H occurs at higher temperatures $\left(400^{\circ} \mathrm{C}-600^{\circ} \mathrm{C}\right.$ for $\mathrm{Ca}(\mathrm{OH})_{2}$ and $600^{\circ} \mathrm{C}-800^{\circ} \mathrm{C}$ for $\left.\mathrm{C}-\mathrm{S}-\mathrm{H}\right)[52,57]$. It may be noted that the mass loss ratio of RAC mix is considerably larger than that of NC mix because concrete with RCA contains more evaporable water than the normal concrete (Table 1) due to the larger water absorption of the former than the latter. The mass loss above $200^{\circ} \mathrm{C}$ is mainly due to the evaporation of gel water at $200^{\circ} \mathrm{C}-400^{\circ} \mathrm{C}$ and crystal water associated with the decomposition of $\mathrm{Ca}(\mathrm{OH})_{2}$ at $400{ }^{\circ} \mathrm{C}-600^{\circ} \mathrm{C}$ or above $[52,56]$.

Fig. 8(b) shows that the addition of steel fiber into RAC has a little effect on the mass loss, especially for specimens with exposure temperature over $200^{\circ} \mathrm{C}$. This is because the addition of steel fibers has some restraint effect on crack development which may hinder the evaporation of moisture at elevated temperatures. However, this may not have any significant effect on the evaporation of moisture which does not rely on the formation of wide cracks.

\subsection{Compressive failure mode}

Compression tests were carried out on the cylinders after the high temperature treatment. Fig. 9 shows the failure modes of different concrete mixes, each representing a random selection from a group of three. 
With the same heat treatment, the failure process and modes for concrete specimens without steel fiber (specimens NC and RAC) were similar. When the stress on the specimen was close to the peak stress, cracking sound could be heard while visible vertical cracks appeared in the concrete. After the peak load, the cracks propagated quickly throughout the specimen. The failure process was rapid, and accordingly stress decreased very quickly. For the cylinders without temperature treatment, the testing machine was stopped only after the stress was reduced to nearly zero at which all the cylinders were nearly crushed, as shown in Fig. 9(a). The specimens shown in Fig. 9(a) were intentionally kept in the test machine for the purpose of taking pictures; otherwise the cylinders would disintegrate so photos of the complete cylinders could not be taken.

From the tests of cylinders without heat treatment, it was found that when the load was decreased to about $20 \%$ of the peak load, total crushing of the cylinder and/or shearing off of concrete debris usually occurred for concrete without steel fibers and major cracks mainly in vertical direction usually appeared for concrete with steel fibers. As a result, $20 \%$ of the peak load was adopted as the criterion to terminate the loading process so that clear pictures as those shown in Figs. 9(b)-(d) could be taken.

As can be seen from Figs. 9(b)-(d), the addition of steel fibers avoided the total disintegration of concrete for cylinders after high temperature treatment. The higher the steel fiber content, the more integral the cylinders after compression test. Furthermore, cracks generally become more zigzag and distributed with an increase of the steel content. It is of interest to note that for cylinders after exposure to $600^{\circ} \mathrm{C}$, the cracks have a tendency to develop between the surface concrete and inner concrete (Fig. 9(d)). The color of the concrete on the cracked surface (yellowish) was apparently different form that of the surface concrete (gray white), suggesting that the temperature gradient exists between the surface concrete and inner concrete which may cause damage to the concrete before the compression test.

\subsection{Stress-strain cures}


The complete stress-strain curve for all specimens was obtained from the compression test of cylinders subjected to a displacement rate of $0.18 \mathrm{~mm} / \mathrm{min}$ as mentioned early. The results are shown in Fig. 10 for all specimens. Three cylinders were tested for each mix. As the test stress-strain curves of the three specimens with the same mix are very close to each other, only one representative curve is shown in Fig. 10 for each concrete mix. The important parameters of the stress-strain curves (e.g. strength, elastic modulus and compressive toughness) were obtained from the average of three specimens with the same mix. It should be noted that for each control specimen, two longitudinal $100 \mathrm{~mm}$ strain gauges were placed at $180^{\circ}$ apart to measure the axial strains in the mid-height region. These gauges were usually out of function due to the cracking of concrete in the later stages of loading, but their readings at the early stages of loading were used for adjusting the setup to minimise the eccentricities of loading. The axial strains were also measured using two linear variable displacement transducers (LVDTs) at $180^{\circ}$ apart and covering $120 \mathrm{~mm}$ at the mid-height region for all specimens following Jiang [51]. All axial strains shown in Fig. 10 are the average of the two LVDTs readings which are generally smaller than those obtained from the full height shortening of the cylinders because of the end effects [27].

Fig. 10 shows that the addition of steel fibers results in a significant change in the shape of the stress-strain curve, with a more flattened descending branch for a concrete mix with larger steel fiber content. The compressive strength and the initial slop of the stress-strain curve are generally reduced with an increase of the exposure temperature; the reduction rate of the latter is much larger than that of the former (see more detailed discussions late). As a result, the strain at the peak stress is increased with the increase of exposure temperature. For example, the strain at the peak stress for the concretes after exposure to $600^{\circ} \mathrm{C}$ is, on average, about 4.8 times of that of the unheated concretes). For RAC, a concrete mix with higher steel fiber content usually has slightly higher strain at the peak stress (see Table 3), which is more obvious at higher exposure temperatures (i.e. $400^{\circ} \mathrm{C}$ and $600^{\circ} \mathrm{C}$ ).

\subsection{Compressive strength}

The residual compressive strength of all concrete cylinders, including both unheated and 
heated specimens, is listed in Table 4. Fig. 11 shows the effects of temperature on the residual compressive strength, where both the actual strength (Fig. 11(a), (c)) and the relative strength with reference to the strength of the corresponding unheated concrete mix (Fig. 11(b)) are shown. It can be seen from Table 4 and Fig. 11 that, for the unheated concrete specimens, a full replacement of NCA by RCA resulted in an increase of $34.62 \%$ in the compressive strength (probably due to water absorbed by RCA). The addition of $0.5 \%, 1 \%$, and $1.5 \%$ of steel fibers in volume led to the reduction of the compressive strength by $9.33 \%, 14.3 \%$ and $18.0 \%$ respectively with respect to the residual strength of RAC without steel fibers as in normal concrete $[53,58]$, which may be due to the stress concentration caused by the non-uniform steel fiber distribution in RAC. The type of steel fiber used may also has an effect on the above strength decrease $[53,58]$.

For RAC specimens (i.e. RAC and SFRACx), the average residual strength after exposure to $200{ }^{\circ} \mathrm{C}$ was $84.6 \%$ of the unheated concrete strength, which was further reduced to $59.0 \%$ and $31.4 \%$ after exposure to $400^{\circ} \mathrm{C}$ and $600^{\circ} \mathrm{C}$ respectively. Figs. 11 (a) and Fig. 11(b) show that the inclusion of steel fiber generally reduces the rate of concrete strength loss. This is more clearly seen at elevated temperatures $400^{\circ} \mathrm{C}$ and $600{ }^{\circ} \mathrm{C}$. Consequently, after exposure to $400^{\circ} \mathrm{C}$ or $600^{\circ} \mathrm{C}$, the steel fiber reinforced RAC retained a higher residual strength than that of the RAC without steel fiber (also see Table 4). Nevertheless, it is of interest to note that the addition of steel fibers also results in a significant decrease of the compressive stress for the concrete specimens heated to $200^{\circ} \mathrm{C}$ as for the unheated concrete specimens, implying that to achieve a balanced compressive strength for both unheated specimens and heated specimens, an appropriate amount of steel fiber content should be used. It is also of interest to note that the concrete mixes suffer quicker loss in compressive strength when the target temperature is higher than $400^{\circ} \mathrm{C}$ (in the range of $400^{\circ} \mathrm{C}-600^{\circ} \mathrm{C}$ ). This might be attributed to that calcium hydroxide $\left(\mathrm{Ca}(\mathrm{OH})_{2}\right)$ usually decomposes at about $400{ }^{\circ} \mathrm{C}-600^{\circ} \mathrm{C}[52,56]$. Compared with NC, RAC mix suffered a faster loss in compressive strength after exposure to elevated temperatures, especially in the temperature range of $200^{\circ} \mathrm{C}-400^{\circ} \mathrm{C}$. This may be attributed to the relatively porous microstructure of recycled concrete aggregate. The faster strength loss of RAC can be well compensated for by incorporating steel fibers as mentioned above (Fig. 11). 
In particular, after exposure to $600^{\circ} \mathrm{C}$, the residual strength of RAC with $1.5 \%$ steel fibers (i.e. SFRAC15) was 1.92 times higher than the RAC without steel fiber, showing the efficiency of steel fibers in allaying the detrimental effect of high temperature on the residual strength of RAC. As the microstructure of RAC and its performance after exposure to high temperature are different from those of conventional concrete [37], the strength degradation mechanism of SFRAC should be further studied by examining the microstructure of concrete, as in [24] and $[31]$.

\subsection{Young's modulus}

The Young's modulus of the concrete specimens was taken as the secant modulus of the corresponding stress-strain curve at one third of the peak stress following Poon et al. [27]. The results are listed in Table 4. Fig. 12 shows the effects of temperature and steel fiber on the Young's modulus. In Fig. 12(b), the modulus was given as the relative value with reference to the Young's modulus of the corresponding unheated concrete. A comparison of results presented in Fig. 11(b) and 12(b) shows that the degradation of Young's modulus is much quicker than that of compressive strength. For RAC specimens, the Young's modulus of the specimens after exposure to $200{ }^{\circ} \mathrm{C}$ was reduced in average to $72.5 \%$ of the unheated concretes. It was further reduced to $22.3 \%$ and $4.61 \%$ after exposure to $400^{\circ} \mathrm{C}$ and $600^{\circ} \mathrm{C}$ respectively, showing that the significant degradation of elastic modulus occurs at temperatures between $200^{\circ} \mathrm{C}$ to $600^{\circ} \mathrm{C}$ which is similar to high strength concrete [59]. The fast degradation of concrete Young's modulus implies that elevated temperature has a significant damage on the microstructure of the concrete cylinders. From Fig. 12(c) it can be seen that for RAC, an increase of the steel fibre content generally reduces the magnitude of the elastic modulus for specimens at room temperature and after exposure to $200^{\circ} \mathrm{C}$, but for specimens after exposure to $400^{\circ} \mathrm{C}$ and $600^{\circ} \mathrm{C}$, the inclusion of steel fiber tends to increase the elastic modulus and only when the steel fiber content reaches $1.5 \%$ does the beneficial effect of steel fiber on the elastic modulus become significant.

\subsection{Energy absorption capacity (toughness)}

In the present study, toughness and specific toughness (termed as "ST" hereafter) are used to 
evaluate the energy absorption capacity of concrete under compression. The ST is defined as the ratio of toughness to the compressive strength of the same specimen. It is well-recognized that the total area under the stress-strain curve should be used to calculate the toughness. However, the recording of the complete stress-strain curve poses many practical challenges, and in the present study, test stress-strain curves were recorded till when the load is reduced to $20 \%$ of the peak load (i.e. at $0.2 f_{c}^{\prime}$ of the descending branch, referred to as " $0.2 f_{c}^{\prime}$ point" for brevity) as explained previously. As a result, the toughness was taken as the area under the stress-strain curve before the $0.20 f_{c}^{\prime}$ point (referred as "stress cut-off" method hereafter) with the results shown in Table 3 and Figs. 13 and 14. It may be noted that a "strain cut-off" method has been used in previous studies (e.g. [27]), but that is inferior compared with the "stress cut-off" method as the former can produce inconsistent results when concretes have different ductility.

The effects of the exposure temperature and steel fiber content on the toughness and the ST are shown in Figs. 13 and 14 respectively. The toughness of each concrete mix has a clear tendency to decrease with the increase of exposure temperature although some variations exist (Fig. 13(a)). In general the degradation rate of toughness is increased when exposure temperature is higher than $400^{\circ} \mathrm{C}$, which may be to attributed to the chemical decomposition of the $\mathrm{Ca}(\mathrm{OH})_{2}$ at temperatures above $400^{\circ} \mathrm{C}$ as mentioned early. Fig. 13(b) shows that the inclusion of steel fiber has a significant beneficial effect on the toughness.

The specific toughness (ST) (Fig. 14) has a tendency in general to increase with an increase of the exposure temperature, in contrast to the apparent decrease of toughness. This means that the degradation rate of concrete strength is higher than that of toughness in the investigated range of exposure temperature. A similar trend was observed by Poon et al. [27] for steel fiber reinforced high performance concrete. Fig. 14(b) demonstrates that the effect of steel fiber content on the ST is similar to those of toughness (Fig. 13(b)), i.e. ST increases with the increase of steel fiber content.

Figs. 13 and 14 that RAC usually has better energy absorption capacity (in terms of both 
toughness and ST) than normal concrete (NC) for a certain range of higher exposure temperatures $\left(200^{\circ} \mathrm{C}-400^{\circ} \mathrm{C}\right)$, although for unheated specimens and specimens after exposure to $600^{\circ} \mathrm{C}$, the energy absorption of RAC is lower than the $\mathrm{NC}$, while such trend does not exist for other mechanical properties, such as compressive strength and elastic modulus (Figs. 11 and 12), showing the complexity in the mechanical behaviors of RAC after exposure to higher temperatures which is an area needing extensive further research.

A comprehensive assessment of the effects of steel fibers on mechanics properties can be conducted by the comparisons among Figs. 11(c), 12(c), 13(b), 14(b). It can be found from the comparisons shows that for unheated RAC, the inclusion of steel fiber generally will lead to a small decrease of both concrete strength and elastic modulus but significant enhance of the energy absorption capacity (in terms of both toughness and ST); for RAC after exposure to high temperatures $\left(>200^{\circ} \mathrm{C}\right)$, the inclusion of steel fiber has beneficial effects for all the three mechanical behaviors (compressive strength, elastic modulus and energy absorption capacity), with the enhancement effects on energy absorption capacity being more significant than on compressive strength and elastic modulus.

\section{Conclusions}

This paper has presented an experimental study on the compressive behavior of steel fiber reinforced recycled aggregate concrete (RAC) after exposure to elevated temperatures. In particular, the effects of steel fibers on the compressive behavior, including strength, elastic modulus and energy absorption capacity have been analyzed in detail. The following conclusions can be drawn from the test results and analyses:

1. Similar to normal concrete (NC), color change was observed on the surface of RAC specimens after exposure to $200^{\circ} \mathrm{C}, 400^{\circ} \mathrm{C}$ and $600^{\circ} \mathrm{C}$ due to chemical and physical changes. Cracks can be identified by naked eyes on the surface of the concrete cylinders after exposure to $400{ }^{\circ} \mathrm{C}$ and $600^{\circ} \mathrm{C}$. The inclusion of steel fibers is effective in restraining the development of crack width, an increase of steel fiber content led to significantly smaller crack width. Explosive spalling was not observed for all specimens during heating 
process, which might be a result of low heating rate $\left(2.5^{\circ} \mathrm{C} / \mathrm{min}\right)$ and the pre-heating process adopted in this study.

2. Elevated temperature has a significant effect on the compressive behavior of RAC: after exposure to $200^{\circ} \mathrm{C}$, the RAC mixes (with or without steel fibres) retained about $85 \%$ of their un-heated compressive strength on average, which was further reduced to $59 \%$ and $31 \%$ after exposure to $400^{\circ} \mathrm{C}$ and $600^{\circ} \mathrm{C}$ respectively. The loss of the stiffness of RAC mixes was much faster than the loss of strength after exposure to elevated temperature; as a result, the strain at peak stress for each RAC mix (with or without steel fibres) was generally increased with an increase of exposure temperature. The loss of specific toughness was a little bit slower than the loss of compressive strength except of the exposure temperature of $200^{\circ} \mathrm{C}$, so the specific toughness (ST) generally tended to increase with an increase of the exposure temperature.

3. For unheated RAC, the inclusion of steel fibers generally caused to a small reduction of both strength and elastic modulus but significant enhancement of the energy absorption capacity (in terms of both toughness and ST). For heat treated RAC, the inclusion of steel fibers has beneficial effects on the compressive strength, elastic modulus and energy absorption capacity, with the enhancement of energy absorption capacity being most significant.

4. RAC usually has better energy absorption capacity in terms of both toughness and specific toughness (ST) than $\mathrm{NC}$ after exposure to high temperatures $\left(200^{\circ} \mathrm{C}\right.$ and $\left.400^{\circ} \mathrm{C}\right)$, although for unheated specimens, the energy absorption of RAC is found to be lower than the NC. Nevertheless, compared with NC, RAC suffers faster decrease in strength and larger mass loss after exposure to high temperatures, showing the complexity in the mechanical behaviors of RAC after exposure to higher temperatures which is an area needing extensive further research.

Effects of elevated temperature on the degradation mechanism of steel fiber reinforced RAC (SFRAC) and how the inclusion of the steel fiber contributes to alleviate the degradation should be further studied by examining the change in the microstructures of concrete in the future. 


\section{Acknowledgments}

The authors gratefully acknowledge financial support provided by Department of Education of Guangdong Province for Excellent Young College Teacher of Guangdong Province (Project No. Yq2013056), National Natural Science Foundation of China (Project Nos. 51278129, 51278132), Guangdong Natural Science Foundation (Project No. S2011010004929) and Guangdong University of Technology via its "One-hundred Talents Plan" program (Project Nos. 112418016, 112418032). They would also like to thank all the staff and technicians in the Structures Laboratory of Guangdong University of Technology for their kind assistance during the tests.

\section{References}

[1] Sagoe-Crentsil KK, Brown T, Taylor AH. Performance of concrete made with commercially produced coarse recycled concrete aggregate. Cement and Concrete Research 2001; 31(5): 707-712.

[2] Kou SC, Poon CS, Etxeberria M. Influence of recycled aggregates on long term mechanical properties and pore size distribution of concrete. Cement and Concrete Composites 2011; 33(2): 286-291.

[3] Xiao JZ, Li WG, Fan YH, et al. An overview of study on recycled aggregate concrete in China (1996-2011). Construction and Building Materials 2012; 31: 364-383.

[4] Xiao JZ, Xie H, Yang ZJ. Shear transfer across a crack in recycled aggregate concrete. Cement and Concrete Research 2012; 42(5): 700-709.

[5] Poon CS, Kou SC, Lam L. Use of recycled aggregates in molded concrete bricks and blocks. Construction and Building Materials 2002; 16(5): 281-289.

[6] Liu Q, Xiao JZ, Sun ZH. Experimental study on the failure mechanism of recycled concrete. Cement and Concrete Research 2011; 41(10): 1050-1057.

[7] Xiao JZ, Li J, Zhang C. Mechanical properties of recycled aggregate concrete under uniaxial loading. Cement and Concrete Research 2005; 35(6): 1187-1194.

[8] Choi WC, Yun HD. Compressive behavior of reinforced concrete columns with recycled aggregate under uniaxial loading. Engineering Structures 2012; 41: 285-293.

[9] Tam VWY, Gao XF, Tam CM. Microstructural analysis of recycled aggregate concrete 
produced from two-stage mixing approach. Cement and Concrete Research 2005;35(6): 1195-1203.

[10] Ajdukiewicz A, Kliszczewicz A. Influence of recycled aggregates on mechanical properties of HS/HPC. Cement and Concrete Composites 2002;24(2): 269-279.

[11] Yang YF, Han LH. Experimental behaviour of recycled aggregate concrete filled steel tubular columns. Journal of Constructional Steel Research 2006;62(12): 1310-1324.

[12] Li XP. Recycling and reuse of waste concrete in China: Part II. Structural behaviour of recycled aggregate concrete and engineering applications. Resources, Conservation and Recycling 2009;53(3): 107-112.

[13] Kou SC, Poon CS. Enhancing the durability properties of concrete prepared with coarse recycled aggregate. Construction and Building Materials 2012;35: 69-76.

[14] Xiao JZ, Huang YJ, Yang J, et al. Mechanical properties of confined recycled aggregate concrete under axial compression. Construction and Building Materials 2012;26(1): $591-603$.

[15] Huang YJ, Xiao JZ, Zhang C. Theoretical study on mechanical behavior of steel confined recycled aggregate concrete. Journal of Constructional Steel Research 2012;76: 100-111.

[16] Katzer J, Domski J. Quality and mechanical properties of engineered steel fibres used as reinforcement for concrete. Construction and Building Materials 2012;34: 243-248.

[17] Nataraja MC, Dhang N, Gupta AP. Stress-strain curves for steel-fiber reinforced concrete under compression. Cement and Concrete Composites 1999;21(5): 383-390.

[18] Mohammadi Y, Singh SP, Kaushik SK. Properties of steel fibrous concrete containing mixed fibres in fresh and hardened state. Construction and Building Materials 2008;22(5): 956-965.

[19] Atiş CD, Karahan O. Properties of steel fiber reinforced fly ash concrete. Construction and Building Materials 2009;23(1): 392-399.

[20] Brandt AM. Fibre reinforced cement-based (FRC) composites after over 40 years of development in building and civil engineering. Composite Structures 2008;86(1): 3-9.

[21] Olivito RS, Zuccarello FA. An experimental study on the tensile strength of steel fiber reinforced concrete. Composites Part B: Engineering 2010;41(3): 246-255.

[22] Yazıcı S, İnan G, Tabak V. Effect of aspect ratio and volume fraction of steel fiber on the 
mechanical properties of SFRC. Construction and Building Materials 2007;21(6): $1250-1253$.

[23] Mesbah HA, Buyle-Bodin F. Efficiency of polypropylene and metallic fibres on control of shrinkage and cracking of recycled aggregate mortars. Construction and Building Materials 1999;13(8): 439-447.

[24] Erdem S, Dawson AR, Thom N H. Microstructure-linked strength properties and impact response of conventional and recycled concrete reinforced with steel and synthetic macro fibres. Construction and Building Materials 2011;25(10): 4025-4036.

[25] Xiao JZ, Falkner H. On residual strength of high-performance concrete with and without polypropylene fibres at elevated temperatures. Fire Safety Journal 2006;41(2): 115-121.

[26] Xiao JZ, König G. Study on concrete at high temperature in China-an overview. Fire safety journal 2004;39(1): 89-103.

[27] Poon CS, Shui ZH, Lam L. Compressive behavior of fiber reinforced high-performance concrete subjected to elevated temperatures. Cement and Concrete Research 2004;34(12): $2215-2222$.

[28] Terro MJ. Properties of concrete made with recycled crushed glass at elevated temperatures. Building and Environment 2006;41(5): 633-639.

[29] Poon CS, Azhar S, Anson M, et al. Strength and durability recovery of fire-damaged concrete after post-fire-curing. Cement and Concrete Research 2001;31(9): 1307-1318.

[30] Peng GF, Yang WW, Zhao J, et al. Explosive spalling and residual mechanical properties of fiber-toughened high-performance concrete subjected to high temperatures. Cement and Concrete Research 2006;36(4): 723-727.

[31] Tai YS, Pan HH, Kung YN. Mechanical properties of steel fiber reinforced reactive powder concrete following exposure to high temperature reaching $800 \mathrm{C}$. Nuclear Engineering and Design 2011;241(7): 2416-2424.

[32] Zega CJ, Di Maio AA. Recycled concrete exposed to high temperatures. Magazine of Concrete Research 2006;58(10): 675-682.

[33] Zega CJ, Di Maio AA. Recycled concrete made with different natural coarse aggregates exposed to high temperature. Construction and Building Materials 2009;23(5): 2047-2052. 
[34] Xiao JZ, Zhang CZ. Fire damage and residual strengths of recycled aggregate concrete. Key Engineering Materials 2007;348: 937-940.

[35] Eguchi K, Teranishi K, Nakagome A, et al. Application of recycled coarse aggregate by mixture to concrete construction. Construction and Building Materials 2007;21(7): $1542-1551$.

[36] Vieira JPB, Correia JR, De Brito J. Post-fire residual mechanical properties of concrete made with recycled concrete coarse aggregates. Cement and Concrete Research 2011;41(5): 533-541.

[37] Cree D, Green M, Noumowé A. Residual strength of concrete containing recycled materials after exposure to fire: A review. Construction and Building Materials 2013;45: 208-223.

[38] Kalifa P, Chene G, Galle C. High-temperature behaviour of HPC with polypropylene fibres: From spalling to microstructure. Cement and concrete research 2001;31(10): 1487-1499.

[39] Poon CS, Azhar S, Anson M, et al. Comparison of the strength and durability performance of normal-and high-strength pozzolanic concretes at elevated temperatures. Cement and Concrete Research 2001;31(9): 1291-1300.

[40] Xiao JZ. Recycled Concrete. Beijing: China Architecture \& Building Press; 2008 [in Chinese].

[41] CECS 13:89. The Testing Methods of Steel Fiber Reinforced Concrete. China Association for Engineering Construction Standardization; 1991[in Chinese].

[42] GB/T 50080. Standard for test method of performance on ordinary fresh concrete. People's Republic of China Building Material Industry Standards; 2002[in Chinese].

[43] Gao DY, Zhao J, Zhu HT. Design and Application of Steel Fiber Reinforced Concrete. Beijing: China Architecture \& Building Press; 2002[in Chinese].

[44] ISO. Fire-resistance tests-elements of building construction-part 1:General requirements, ISO 834-1:1999. Geneva, Switzerland: International Organization for Standardization; 1999.

[45] Bisby LA, Chen JF, Li SQ, Stratford, TJ, Cueva N, Crossling K. Strengthening fire-damaged concrete by confinement with fibre-reinforced polymer wraps. Engineering 
Structures 2011; 33:3381-3391.

[46] Çavdar A. A study on the effects of high temperature on mechanical properties of fiber reinforced cementitious composites. Composites Part B: Engineering 2012;43(5): 2452-2463.

[47] Husem M. The effects of high temperature on compressive and flexural strengths of ordinary and high-performance concrete. Fire Safety Journal 2006;41(2): 155-163.

[48] Rahim A, Sharma UK, Murugesan K, et al. Multi-response optimization of post-fire residual compressive strength of high performance concrete. Construction and Building Materials 2013;38: 265-273.

[49] Zheng WZ, Li HY, Wang Y. Compressive stress-strain relationship of steel fiber-reinforced reactive powder concrete after exposure to elevated temperatures. Construction and Building Materials 2012;35: 931-940.

[50] ASTM C39. Standard Test Method for Compressive Strength of Cylindrical Concrete Specimens; 2009.

[51] Jiang T. FRP-confined RC columns: analysis, behavior and design. Ph.D. dissertation, The Hong Kong Polytechnic University; 2008.

[52] Zheng WZ, Li HY, Wang Y. Compressive behaviour of hybrid fiber-reinforced reactive powder concrete after high temperature. Materials \& Design 2012;41: 403-409.

[53] Lau A, Anson M. Effect of high temperatures on high performance steel fibre reinforced concrete. Cement and Concrete Research 2006;36(9): 1698-1707.

[54] Ozawa M, Uchida S, Kamada T, et al. Study of mechanisms of explosive spalling in high-strength concrete at high temperatures using acoustic emission. Construction and Building Materials 2012;37: 621-628.

[55] Kodur VKR, Sultan MA. Effect of temperature on thermal properties of high-strength concrete. Journal of materials in civil engineering, 2003, 15(2): 101-107.

[56] Savva A, Manita P, Sideris KK. Influence of elevated temperatures on the mechanical properties of blended cement concretes prepared with limestone and siliceous aggregates. Cement and Concrete Composites 2005;27(2): 239-248.

[57] Zhang BS. Effects of moisture evaporation (weight loss) on fracture properties of high 
performance concrete subjected to high temperatures. Fire Safety Journal 2011;46(8): 543-549.

[58] Gao DY, Lou ZH, Wang ZQ. Experimental study on the compressive strength of steel fiber recycled concrete. Journal of Zhengzhou University (Engineering Science) 2007;28(2): 5-10 [in Chinese].

[59] $\mathrm{Wu} \mathrm{B}, \mathrm{Su}$ X, Li H, et al. Effect of high temperature on residual mechanical properties of confined and unconfined high-strength concrete[J]. ACI Materials Journal 2002;99(4): $399-407$ 


\section{LIST OF TABLES}

Table 1. Mix proportions $\left(\mathrm{kg} / \mathrm{m}^{3}\right)$ and cube compressive strength (28 day and 1 year)

Table 2. Maximum crack width of concrete cylinders after exposure to $400^{\circ} \mathrm{C}$ and $600^{\circ} \mathrm{C}, \mathrm{mm}$

Table 3. Effect of temperature on deformability and ductility of concrete

Table 4. Compressive strength and Young's modulus of concrete cylinders 


\section{LIST OF FIGURES}

Fig. 1 Coarse aggregates and steel fibres

Fig. 2 Furnace temperature-time curve

Fig. 3 Test setup and locations of LVDTs and strain gauges

Fig. 4 Concrete cylinders after exposure to elevated temperatures

Fig. 5 Maximum crack width of concrete cylinders after exposure to $400^{\circ} \mathrm{C}$

Fig. 6 Maximum crack width of concrete cylinders after exposure to $600^{\circ} \mathrm{C}$

Fig. 7 Maximum crack width of concrete specimens

Fig. 8 Mass loss ratio due to exposure to elevated temperature

Fig. 9 Failure mode of cylinders after exposure to elevated temperatures

Fig. 10 Stress-axial strain curve of concrete after exposure to elevated temperature

Fig. 11 Effect of temperature on concrete compressive strength

Fig. 12 Effect of temperature on Young's modulus of concrete

Fig. 13 Toughness of unheated and heated concrete mixes (stress cut-off method)

Fig. 14 Specific toughness of unheated and heated concrete mixes (stress cut-off method) 


\section{Table 1}

Mix proportions $\left(\mathrm{kg} / \mathrm{m}^{3}\right)$ and cube compressive strength (28 day and 1 year)

\begin{tabular}{|c|c|c|c|c|c|c|c|c|c|c|c|c|}
\hline \multirow{4}{*}{ Mix } & \multicolumn{10}{|c|}{ Mix proportions } & \multirow{4}{*}{$\begin{array}{c}28 \text { day } \\
\text { cube } \\
\text { strength, } \\
\mathrm{MPa}\end{array}$} & \multirow{4}{*}{$\begin{array}{l}1 \text { year } \\
\text { cube } \\
\text { Strength, } \\
\mathrm{MPa}\end{array}$} \\
\hline & \multirow[t]{3}{*}{$\mathrm{W} / \mathrm{C}$} & \multirow[t]{3}{*}{ W } & \multirow[t]{3}{*}{$\mathrm{PC}$} & \multirow[t]{3}{*}{ Sand } & \multirow[t]{3}{*}{$\mathrm{NCA}$} & \multicolumn{2}{|c|}{ RCA } & \multirow[t]{3}{*}{$\mathrm{AW}$} & \multirow[t]{3}{*}{ SF } & \multirow[t]{3}{*}{ WRA } & & \\
\hline & & & & & & FRCA & CRCA & & & & & \\
\hline & & & & & & & & & & & & \\
\hline $\mathrm{NC}$ & 0.46 & 203.28 & 440 & 670 & 1092 & & & & & 6.6 & 64.9 & 66.3 \\
\hline RAC & 0.46 & 203.28 & 440 & 670 & & 585 & 390 & 30 & & 6.6 & 57.9 & 72.6 \\
\hline SFRAC5 & 0.46 & 203.28 & 440 & 670 & & 585 & 390 & 30 & 39 & 6.6 & 55.3 & 64.3 \\
\hline SFRAC10 & 0.46 & 203.28 & 440 & 670 & & 585 & 390 & 30 & 78 & 6.6 & 51.9 & 63.8 \\
\hline SFRAC15 & 0.46 & 203.28 & 440 & 670 & & 585 & 390 & 30 & 117 & 6.6 & 52.3 & 68.3 \\
\hline
\end{tabular}

Note: $\mathrm{NC}=$ natural aggregate concrete, $\mathrm{RAC}=$ for recycled aggregate concrete, SFRAC5、SFRAC10、SFRAC15 = steel fibre volume fraction $0.5 \%, 1 \% 、 1.5 \%$ respectively, $\mathrm{W} / \mathrm{C}=$ water/cement ratio $(\mathrm{mass}), \mathrm{W}=$ water, $\mathrm{OPC}=$ ordinary Portland cement, $\mathrm{NCA}=$ natural coarse aggregate, $\mathrm{RCA}=$ recycled concrete aggregate, $\mathrm{FRCA}=$ fine recycled concrete aggregate, $\mathrm{CRCA}=$ coarse recycled concrete aggregate, $\mathrm{AW}=$ additional water, $\mathrm{SF}=$ steel fiber, $\mathrm{WRA}=$ naphthalene-based high efficiency water-reducing admixture. 


\section{Table 2}

Maximum crack widths of concrete cylinders after exposure to $400^{\circ} \mathrm{C}$ and $600{ }^{\circ} \mathrm{C}, \mathrm{mm}$

\section{Exposure temperature}

\begin{tabular}{ccccccccc} 
Mix & \multicolumn{4}{c}{$400^{\circ} \mathrm{C}$} & \multicolumn{5}{c}{$600^{\circ} \mathrm{C}$} \\
\cline { 2 - 8 } & 1 & 2 & 3 & Mean & 1 & 2 & 3 & Mean \\
\hline NC & 0.20 & 0.20 & 0.28 & 0.23 & 0.54 & 0.72 & 0.78 & 0.68 \\
RAC & 0.24 & 0.28 & 0.16 & 0.23 & 0.66 & 0.72 & 0.78 & 0.72 \\
SFRAC5 & 0.08 & 0.14 & 0.14 & 0.12 & 0.44 & 0.36 & 0.34 & 0.38 \\
SFRAC10 & 0.10 & 0.08 & 0.10 & 0.09 & 0.36 & 0.26 & 0.32 & 0.31 \\
SFRAC15 & 0.06 & 0.10 & 0.06 & 0.07 & 0.12 & 0.18 & 0.16 & 0.15 \\
\hline
\end{tabular}




\section{Table 3}

Effect of temperature on deformability and ductility of concrete

\begin{tabular}{|c|c|c|c|c|c|c|c|c|c|c|c|c|c|c|c|c|c|}
\hline \multirow{2}{*}{$\mathrm{T}\left({ }^{\circ} \mathrm{C}\right)$} & \multirow{2}{*}{ Mix } & \multicolumn{4}{|c|}{ Strength fc' (MPa) } & \multicolumn{4}{|c|}{ Strain at peak stress $(\%)$} & \multicolumn{4}{|c|}{ Toughness (MPa) } & \multicolumn{4}{|c|}{ Specific toughness (\%) } \\
\hline & & 1 & 2 & 3 & mean & 1 & 2 & 3 & mean & 1 & 2 & 3 & mean & 1 & 2 & 3 & mean \\
\hline \multirow{5}{*}{ AT } & $\mathrm{NC}$ & 43.33 & 36.81 & 38.56 & 39.57 & 0.30 & 0.34 & 0.43 & 0.36 & 0.20 & 0.40 & 0.35 & 0.32 & 0.47 & 1.09 & 0.90 & 0.82 \\
\hline & RAC & 54.92 & 52.39 & 52.49 & 53.27 & 0.34 & 0.32 & 0.31 & 0.32 & 0.30 & 0.17 & 0.34 & 0.27 & 0.55 & 0.33 & 0.66 & 0.51 \\
\hline & SFRAC5 & 46.94 & 50.93 & 47.04 & 48.30 & 0.34 & 0.29 & 0.34 & 0.32 & 0.57 & 0.60 & 0.59 & 0.58 & 1.21 & 1.17 & 1.24 & 1.21 \\
\hline & SFRAC10 & 45.48 & 47.81 & 43.72 & 45.67 & 0.38 & 0.34 & 0.38 & 0.37 & 0.78 & 0.79 & 0.80 & 0.79 & 1.72 & 1.66 & 1.84 & 1.74 \\
\hline & SFRAC15 & 42.46 & 43.14 & 45.48 & 43.69 & 0.54 & 0.44 & 0.38 & 0.45 & 0.91 & 0.77 & 0.78 & 0.82 & 2.14 & 1.79 & 1.73 & 1.89 \\
\hline \multirow{5}{*}{200} & $\mathrm{NC}$ & 34.96 & 36.85 & 39.15 & 36.99 & 0.31 & 0.37 & 0.29 & 0.32 & - & 0.14 & - & 0.14 & - & 0.37 & - & 0.37 \\
\hline & RAC & 44.41 & 42.27 & 43.33 & 43.34 & 0.31 & 0.33 & 0.29 & 0.31 & 0.14 & 0.15 & 0.24 & 0.18 & 0.33 & 0.36 & 0.56 & 0.42 \\
\hline & SFRAC5 & 41.97 & 38.76 & 40.51 & 40.41 & 0.25 & 0.32 & 0.30 & 0.29 & 0.35 & 0.32 & 0.32 & 0.33 & 0.83 & 0.82 & 0.79 & 0.81 \\
\hline & SFRAC10 & 36.42 & 40.71 & 40.22 & 39.12 & 0.33 & 0.34 & 0.38 & 0.35 & 0.54 & 0.45 & $*$ & 0.49 & 1.49 & 1.10 & $*$ & 1.29 \\
\hline & SFRAC15 & 38.56 & 37.59 & 39.54 & 38.56 & 0.44 & 0.47 & 0.49 & 0.47 & 0.71 & 0.82 & 0.92 & 0.82 & 1.85 & 2.18 & 2.33 & 2.12 \\
\hline \multirow{5}{*}{400} & $\mathrm{NC}$ & 29.12 & 25.12 & 28.73 & 27.66 & 0.50 & 0.62 & 0.52 & 0.55 & - & 0.20 & 0.17 & 0.18 & - & 0.79 & 0.59 & 0.69 \\
\hline & RAC & 27.56 & 20.94 & 26.49 & 25.00 & 0.56 & 0.48 & 0.58 & 0.54 & 0.28 & 0.15 & 0.31 & 0.24 & 1.01 & 0.71 & 1.15 & 0.96 \\
\hline & SFRAC5 & 30.68 & 24.25 & 29.31 & 28.08 & 0.52 & 0.74 & 0.52 & 0.59 & 0.33 & 0.27 & 0.20 & 0.26 & 1.09 & 1.09 & 0.67 & 0.95 \\
\hline & SFRAC10 & 27.66 & 25.32 & 29.02 & 27.33 & 0.63 & 0.70 & 0.81 & 0.71 & 0.63 & 0.68 & 0.46 & 0.59 & 2.30 & 2.69 & 1.57 & 2.18 \\
\hline & SFRAC15 & 32.82 & 29.7 & 34.28 & 32.27 & 0.65 & 0.91 & 0.59 & 0.72 & 0.48 & $*$ & 0.84 & 0.66 & 1.47 & $*$ & 2.45 & 1.96 \\
\hline \multirow{5}{*}{600} & $\mathrm{NC}$ & 12.95 & 11.30 & 11.69 & 11.98 & 1.13 & 1.56 & 1.59 & 1.43 & - & 0.22 & 0.16 & 0.22 & - & 1.94 & - & 1.94 \\
\hline & RAC & 12.37 & 11.00 & 10.61 & 11.33 & 1.38 & 1.31 & 1.17 & 1.29 & 0.21 & 0.17 & - & 0.15 & 1.66 & 1.58 & 0.54 & 1.26 \\
\hline & SFRAC5 & 13.24 & 12.37 & 13.54 & 13.05 & 1.33 & 1.23 & 1.18 & 1.25 & 0.25 & 0.23 & 0.25 & 0.25 & 1.91 & 1.90 & 1.84 & 1.89 \\
\hline & SFRAC10 & 13.05 & 14.02 & 14.12 & 13.73 & 1.20 & 1.79 & 1.47 & 1.49 & 0.31 & - & 0.30 & 0.30 & 2.34 & - & 2.14 & 2.24 \\
\hline & SFRAC15 & 22.69 & 21.03 & 21.72 & 21.81 & 1.24 & 1.51 & 1.36 & 1.37 & 0.42 & 0.51 & 0.59 & 0.51 & 1.85 & 2.42 & 2.70 & 2.32 \\
\hline
\end{tabular}

Note: AT=Ambient temperature around $25^{\circ} \mathrm{C}$; “-” malfunction of LVDTs; “*” unexpected stop of testing machine. 


\section{Table 4}

Compressive strength and Young's modulus of concrete cylinders

\begin{tabular}{cccccccccc}
\hline & Slump & \multicolumn{3}{c}{ Compressive strength $(\mathrm{MPa})$} & \multicolumn{3}{c}{ Young's modulus (GPa) } \\
\cline { 3 - 9 } Mix & $(\mathrm{mm})$ & AT & $200^{\circ} \mathrm{C}$ & $400^{\circ} \mathrm{C}$ & $600^{\circ} \mathrm{C}$ & AT & $200^{\circ} \mathrm{C}$ & $400^{\circ} \mathrm{C}$ & $600^{\circ} \mathrm{C}$ \\
\hline NC & 198 & 39.57 & 36.99 & 27.66 & 11.98 & 23.80 & 17.65 & 5.90 & 0.57 \\
RAC & 187 & 53.27 & 43.34 & 25.00 & 11.33 & 27.23 & 19.07 & 5.37 & 0.74 \\
SFRAC5 & 154 & 48.30 & 40.41 & 28.08 & 13.05 & 26.80 & 19.43 & 5.49 & 0.93 \\
SFRAC10 & 151 & 45.67 & 39.12 & 27.33 & 13.73 & 24.13 & 16.86 & 5.00 & 0.84 \\
SFRAC15 & 110 & 43.69 & 38.56 & 32.27 & 21.81 & 20.89 & 16.46 & 6.21 & 2.06 \\
\hline
\end{tabular}

Note: $\mathrm{AT}=\mathrm{Ambient}$ temperature around $25^{\circ} \mathrm{C}$. 


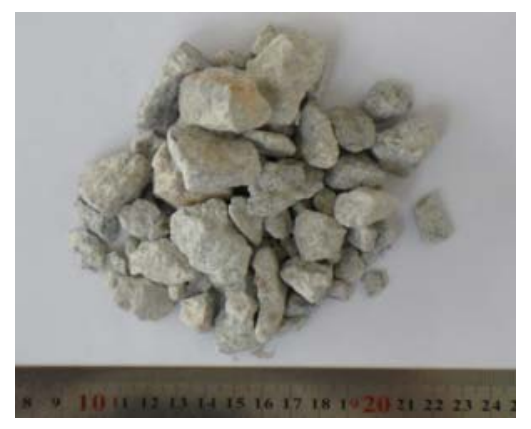

(a) NCA

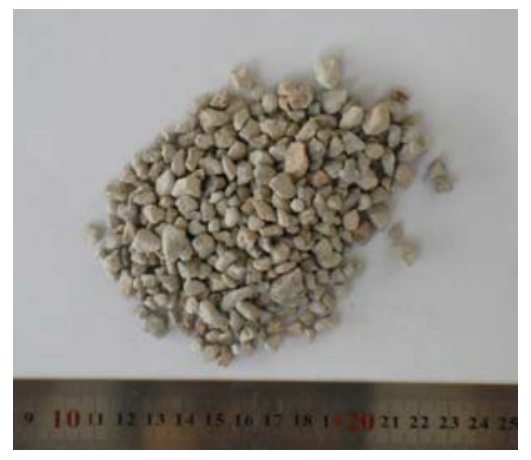

(b) FRCA

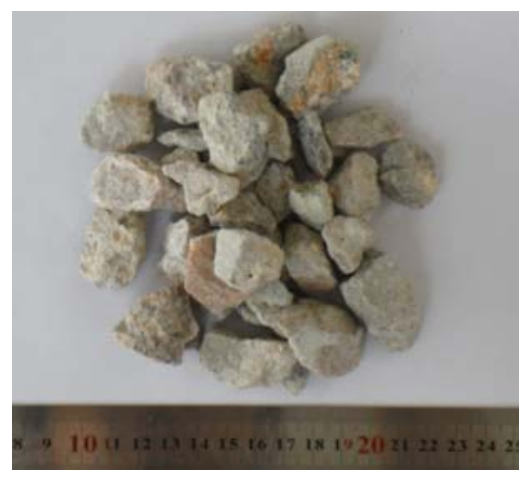

(c) CRCA

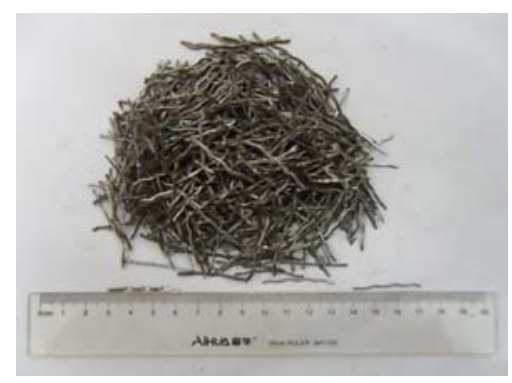

(d) Steel fibers

Fig. 1. Coarse aggregates and steel fibres

$(\mathrm{NCA}=$ natural coarse aggregate, $\mathrm{RCA}=$ recycled concrete aggregate, $\mathrm{FRCA}=$ fine recycled concrete aggregate, $\mathrm{CRCA}=$ coarse recycled concrete aggregate) 


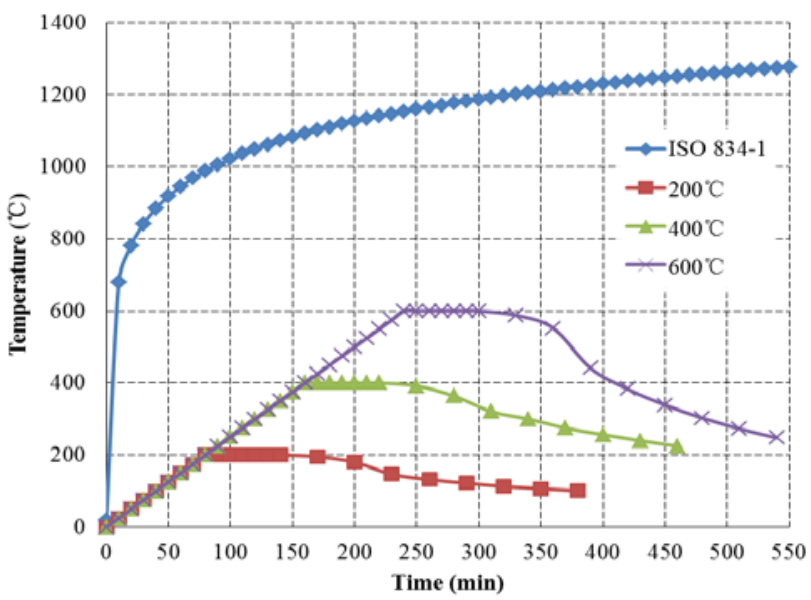

Fig. 2. Furnace temperature-time curve. 


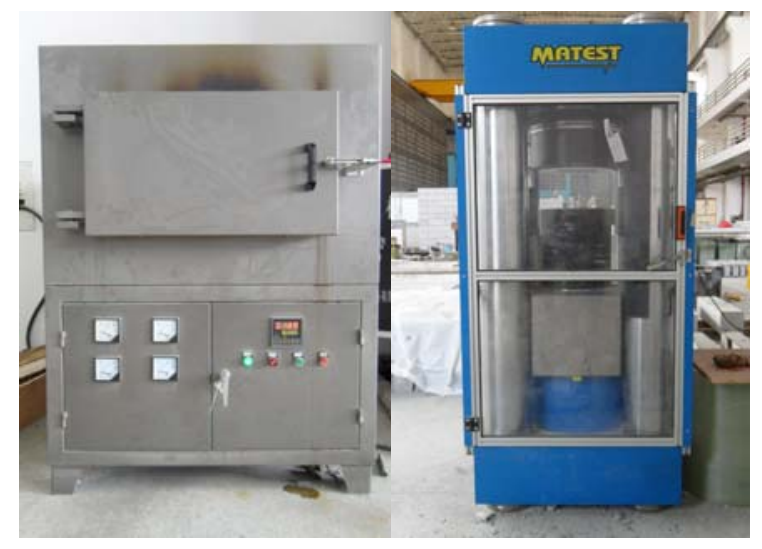

(a) Test setup

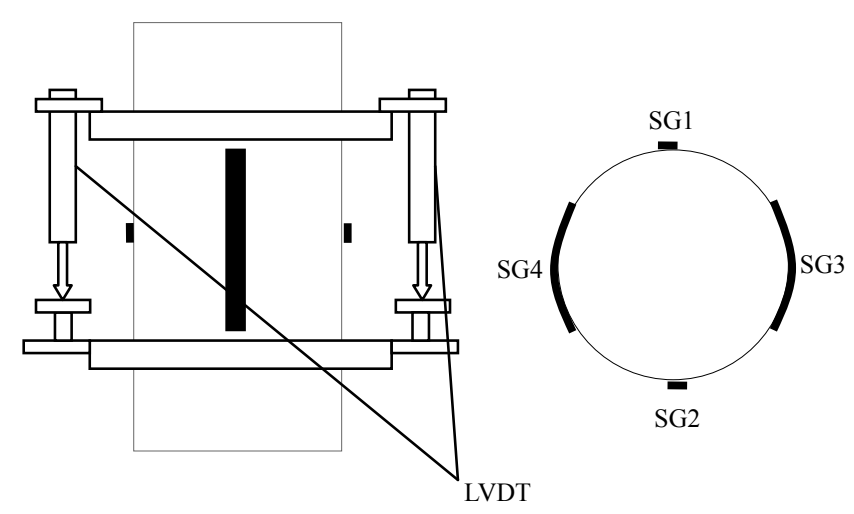

(b) Location of LVDTs and strain gauges

Fig. 3. Test setup and locations of LVDTs and strain gauges. 


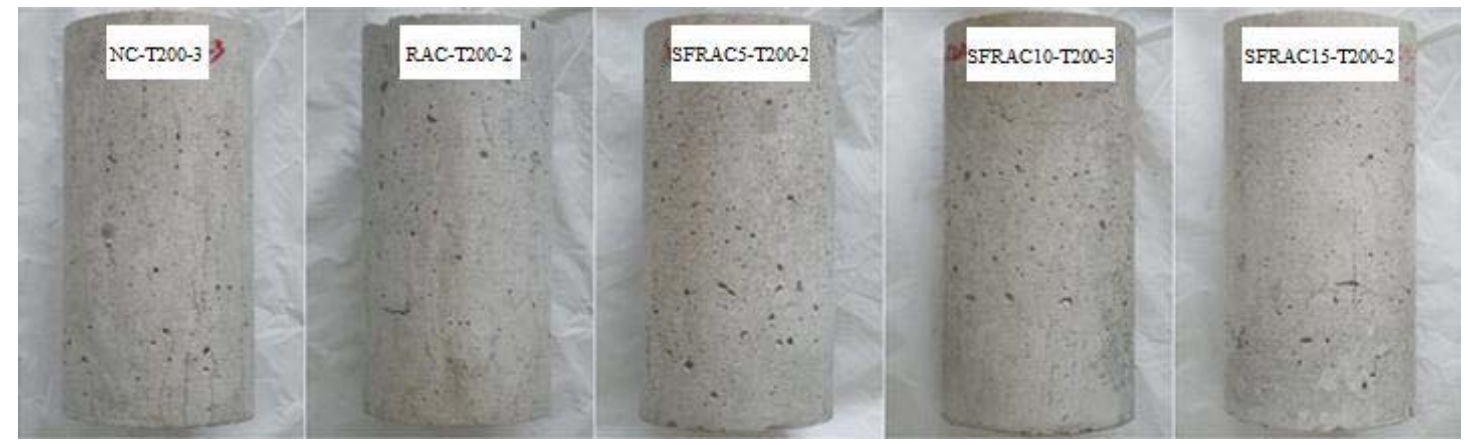

(a) Concrete cylinders after exposure to $200^{\circ} \mathrm{C}$

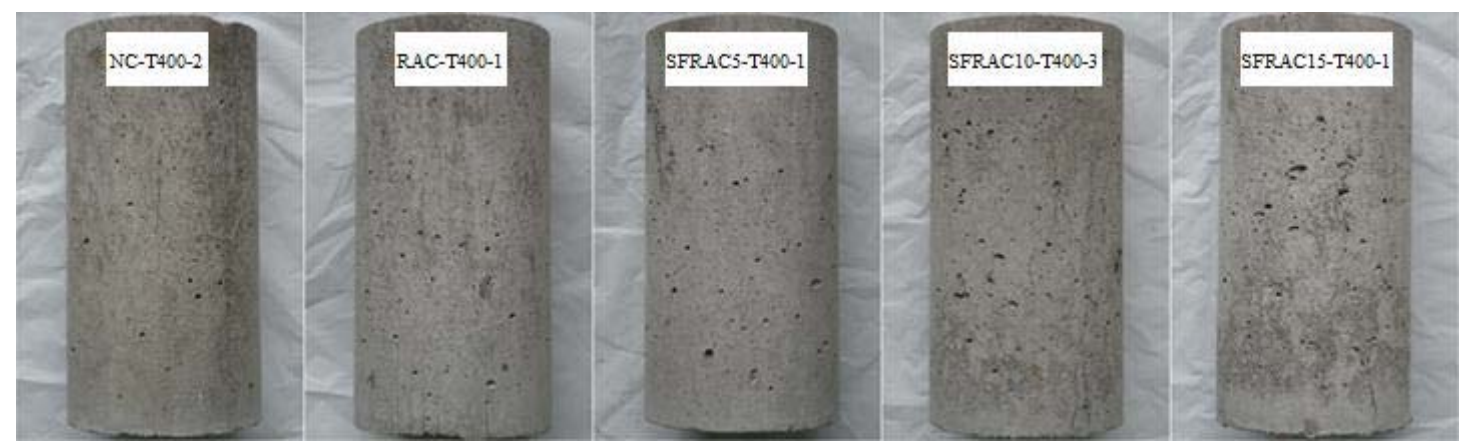

(b) Concrete cylinders after exposure to $400^{\circ} \mathrm{C}$

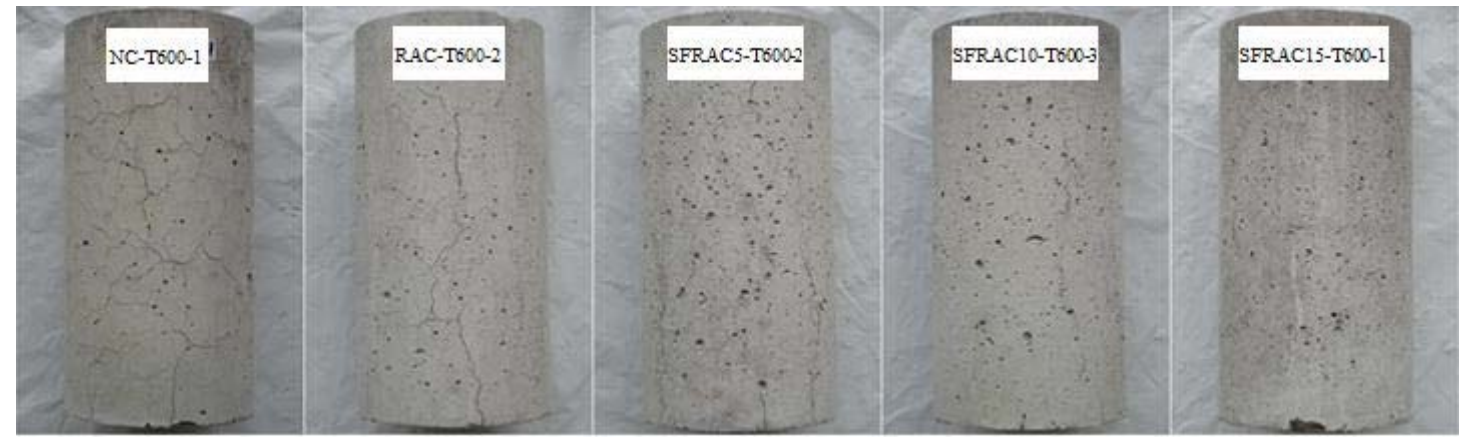

(c) Concrete cylinders after exposure to $600^{\circ} \mathrm{C}$

Fig. 4. Concrete cylinders after exposure to elevated temperatures. 

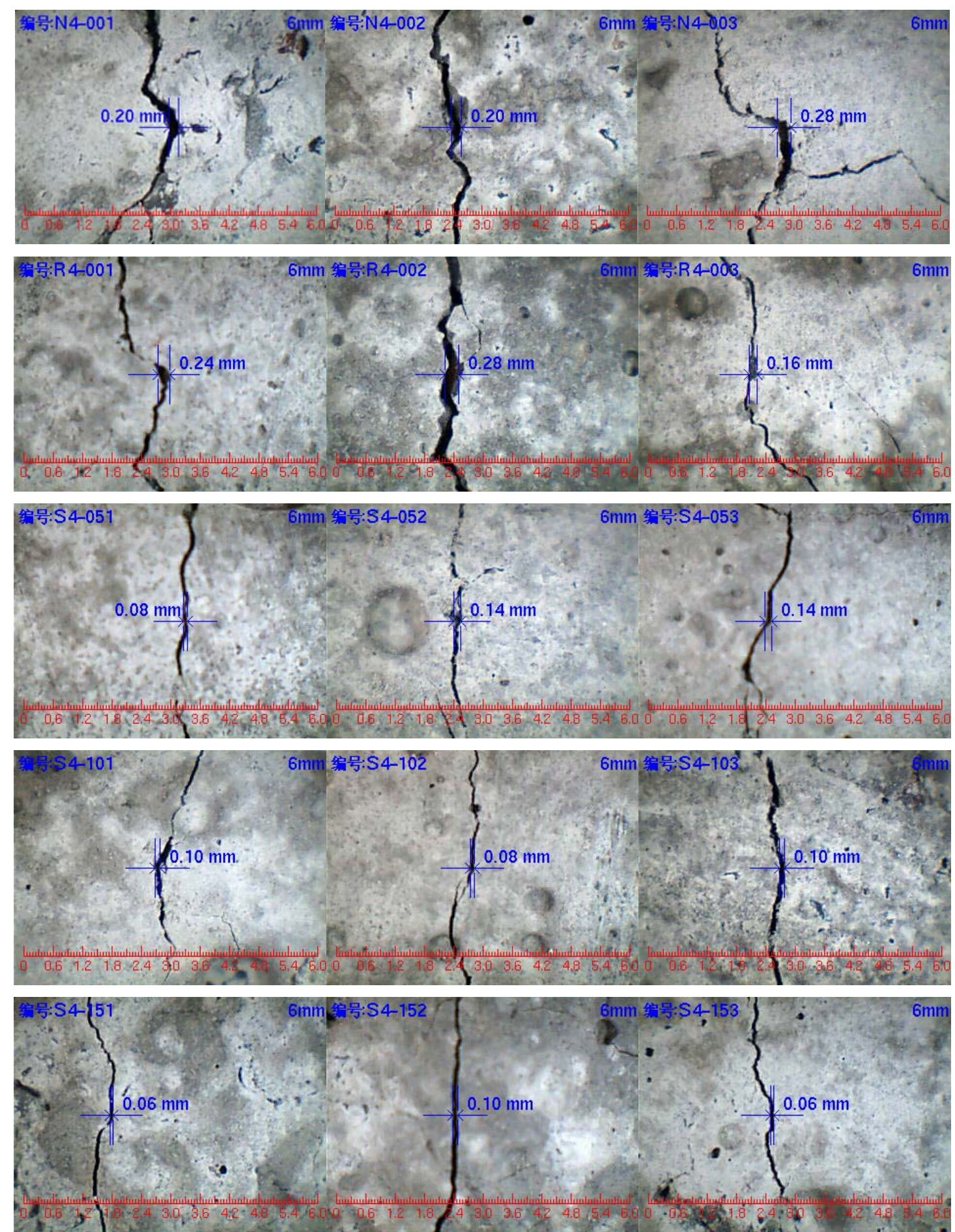

Fig. 5. Maximum crack width of concrete cylinders after exposure to $400^{\circ} \mathrm{C}$. 

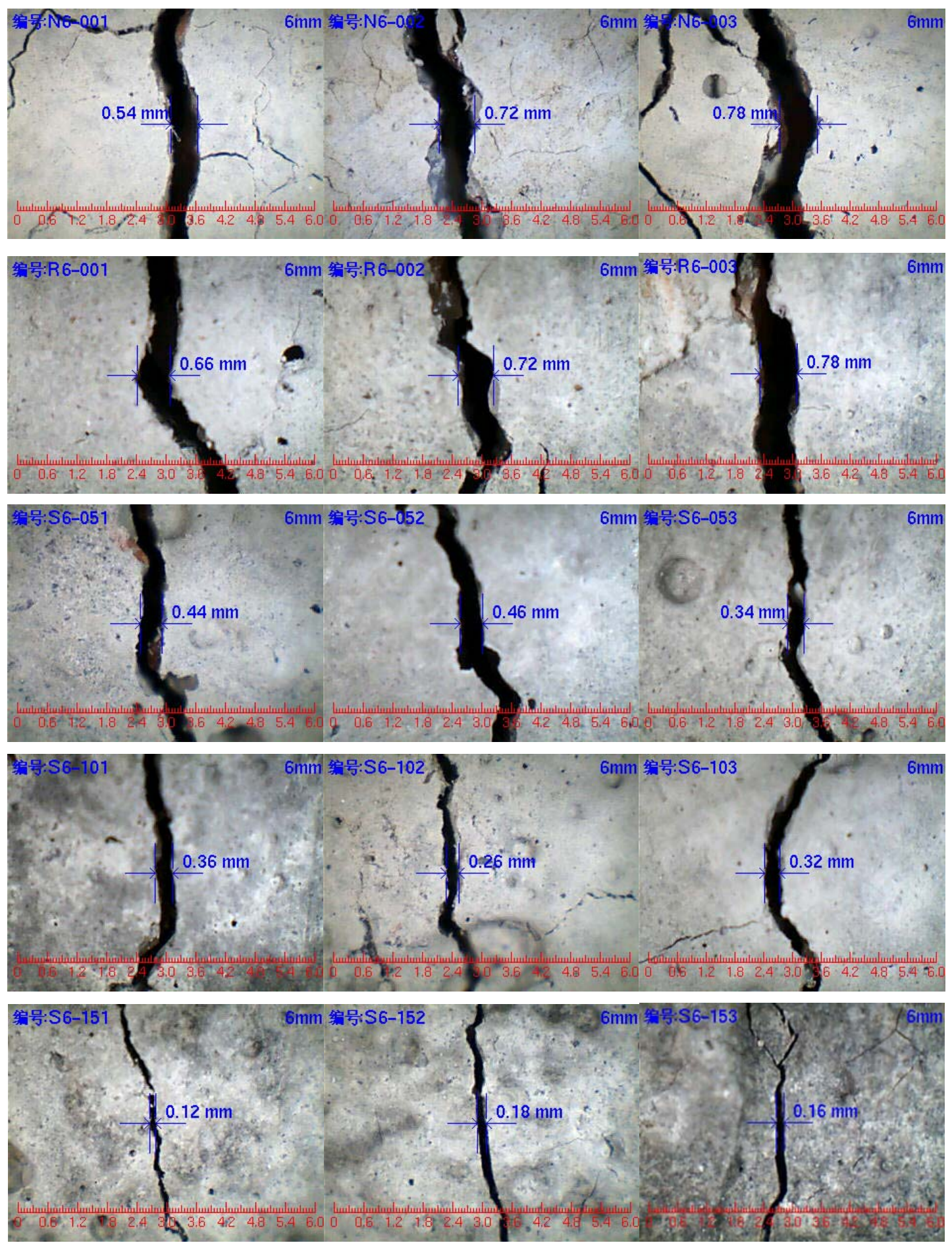

Fig. 6. Maximum crack width of concrete cylinders after exposure to $600^{\circ} \mathrm{C}$. 


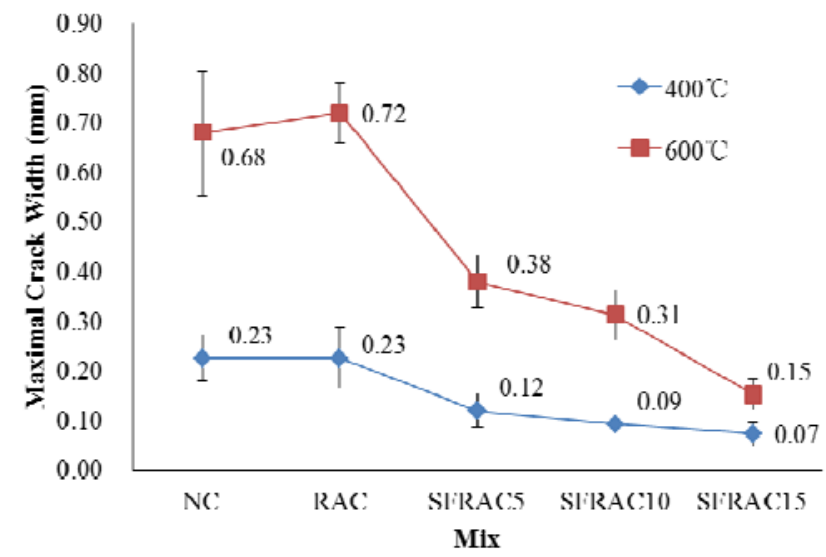

Fig. 7. Maximum crack width of concrete specimens. 


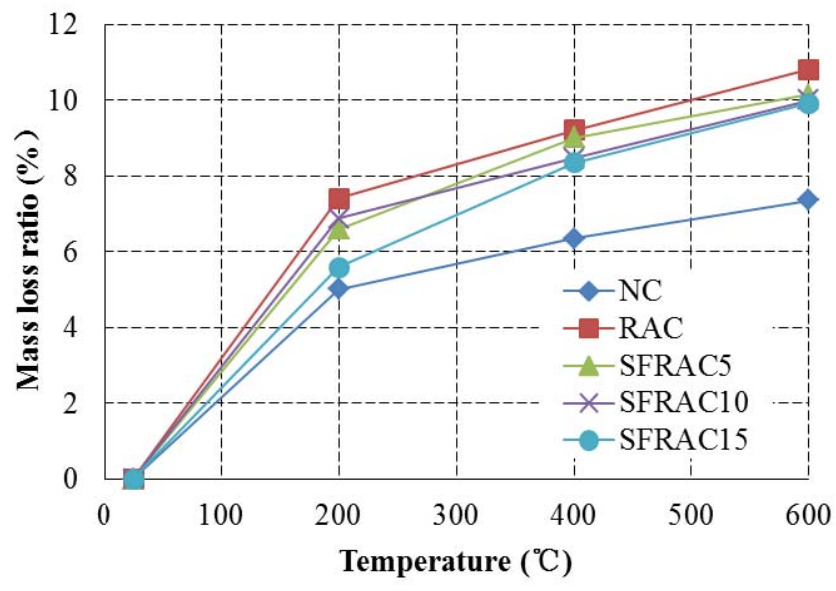

(a) Effect of exposure temperature on mass loss

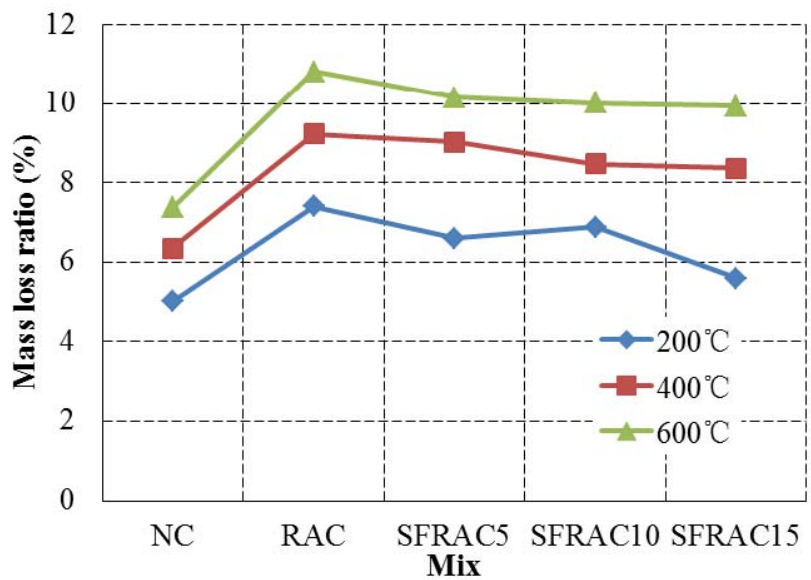

(b) Effect of steel fiber content on mass loss

Fig. 8. Mass loss ratio due to exposure to elevated temperature. 

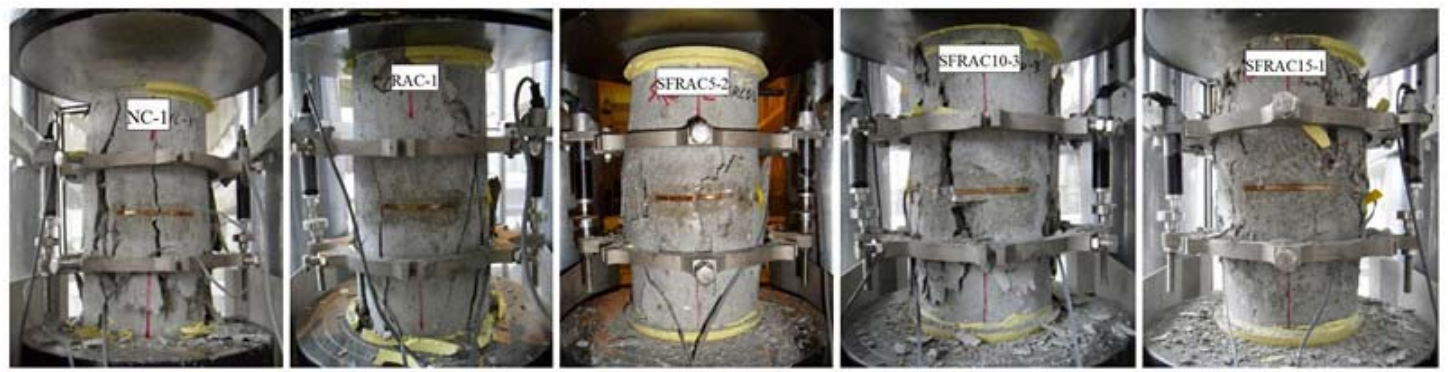

(a) Failure mode of cylinders without high temperature exposure
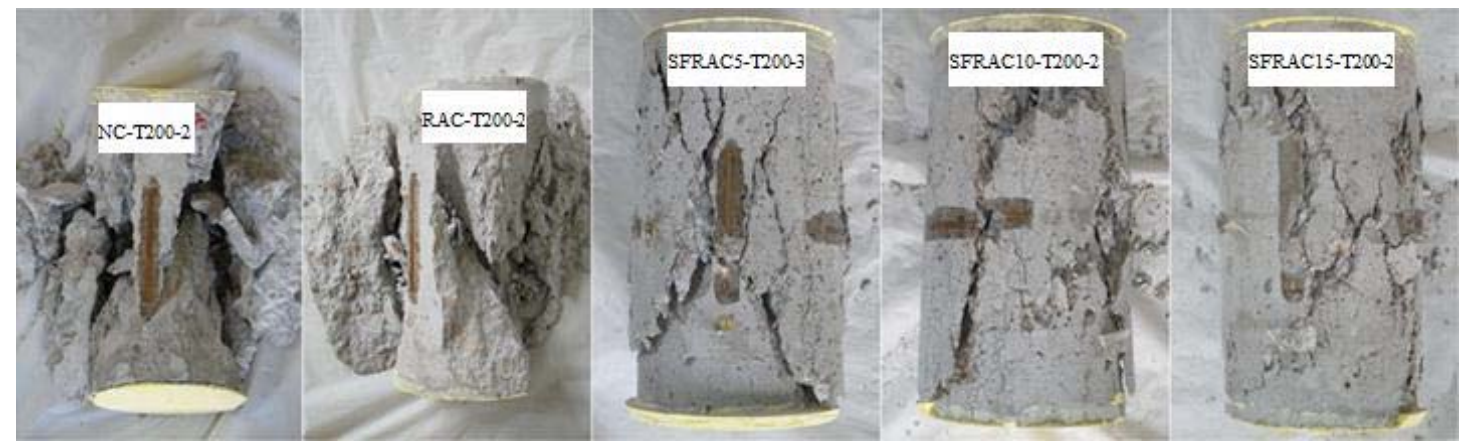

(b) Failure mode of cylinders after exposure to $200^{\circ} \mathrm{C}$

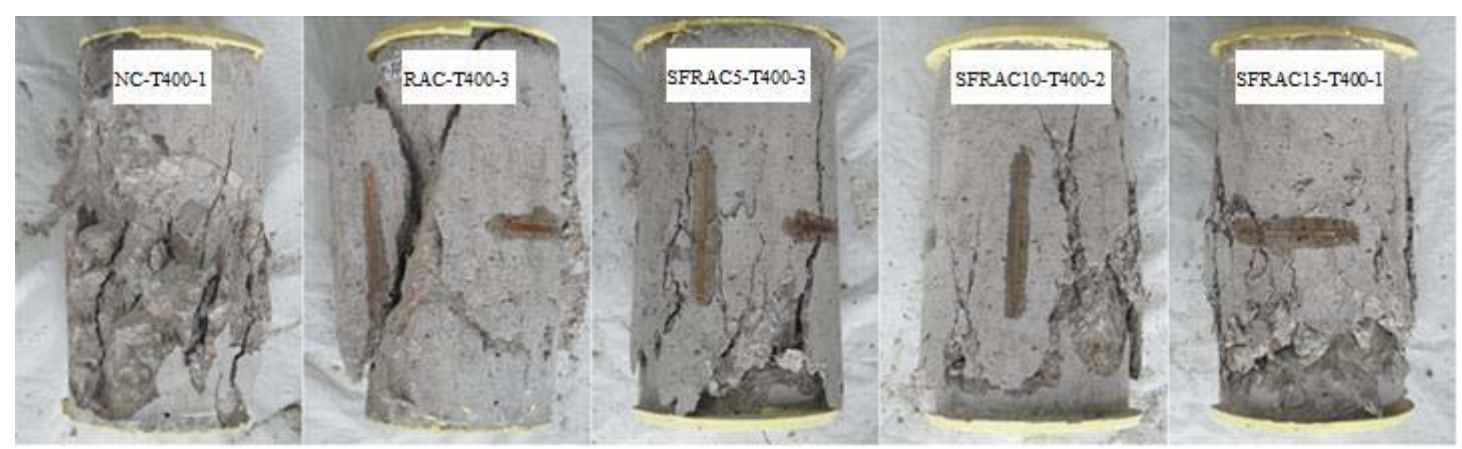

(c) Failure mode of cylinders after exposure to $400^{\circ} \mathrm{C}$

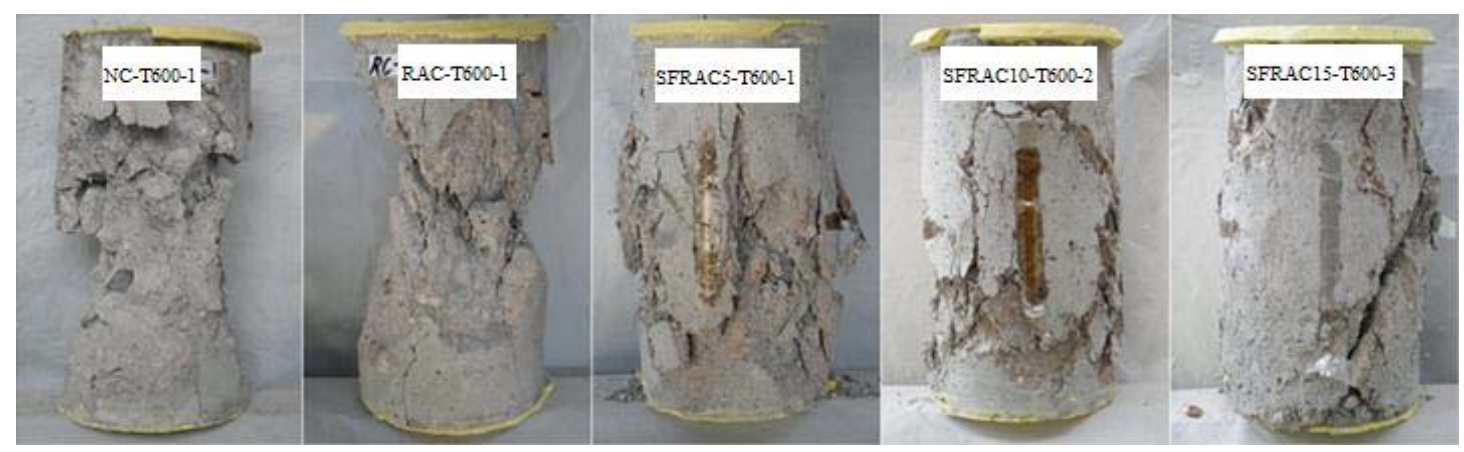

(d) Failure mode of cylinders after exposure to $600^{\circ} \mathrm{C}$

Fig. 9. Failure mode of cylinders after exposure to elevated temperatures. 


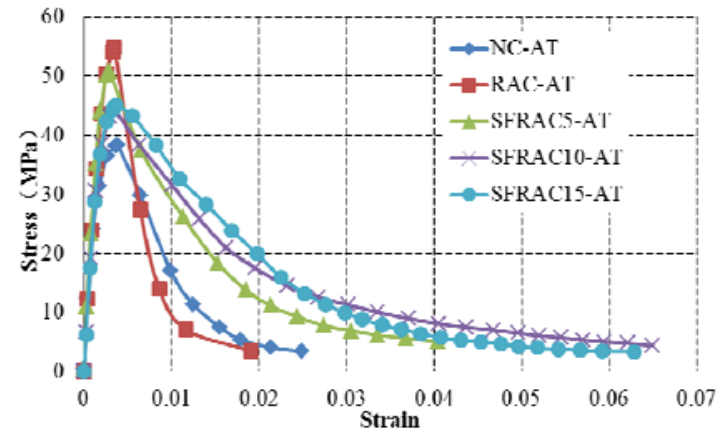

(a) Axial stress-strain curve of unheated concrete cylinders

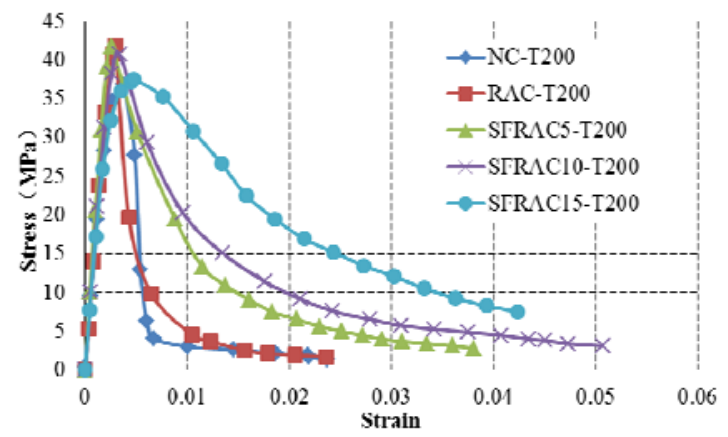

(b) Axial stress-strain curve of concrete after exposure to $200^{\circ} \mathrm{C}$

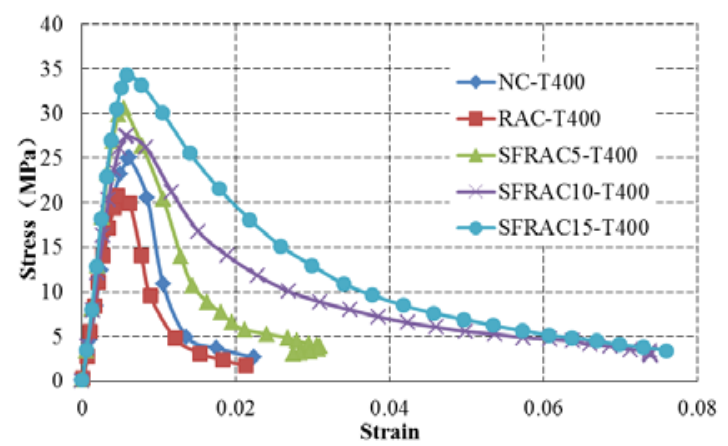

(c) Axial stress-strain curve of concrete after exposure to $400^{\circ} \mathrm{C}$

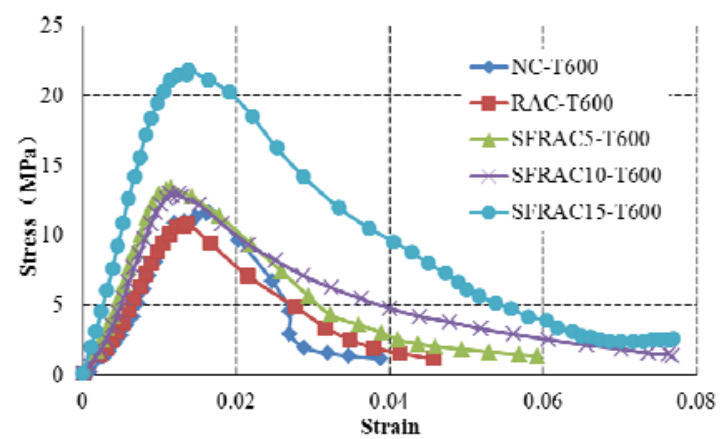

(d) Axial stress-strain curve of concrete after exposure to $600^{\circ} \mathrm{C}$

Fig. 10. Axial stress-strain curve of concrete after exposure to elevated temperature. 


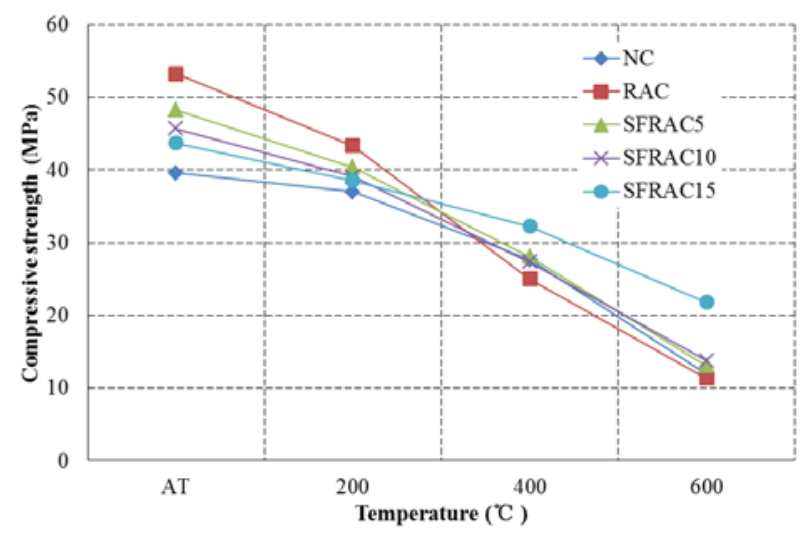

(a) Effect of exposure temperature on compressive strength

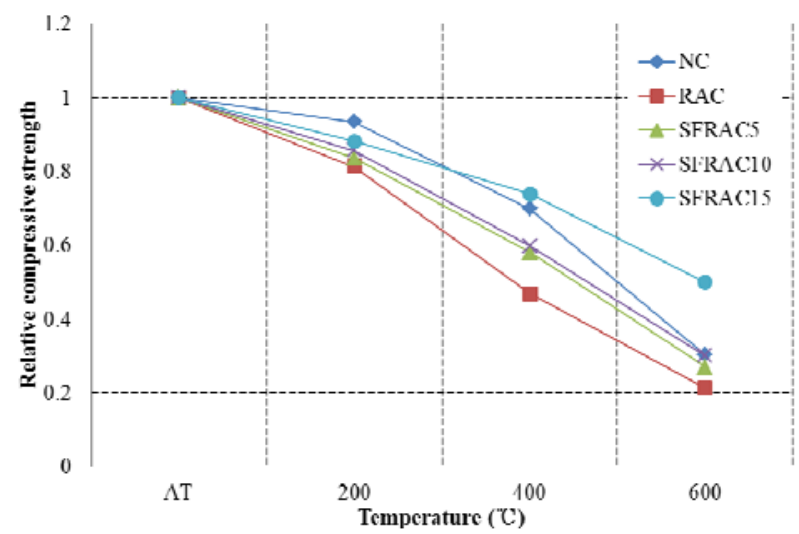

(b) Effect of exposure temperature on relative compressive strength

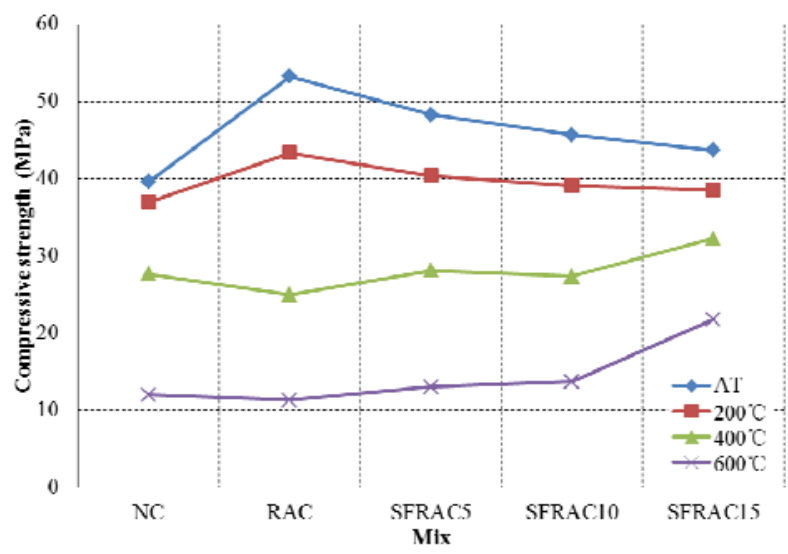

(c) Effect of steel fiber content on compressive strength

Fig. 11. Effect of temperature on concrete compressive strength $(\mathrm{AT}=$ Ambient temperature around $25^{\circ} \mathrm{C}$ ). 


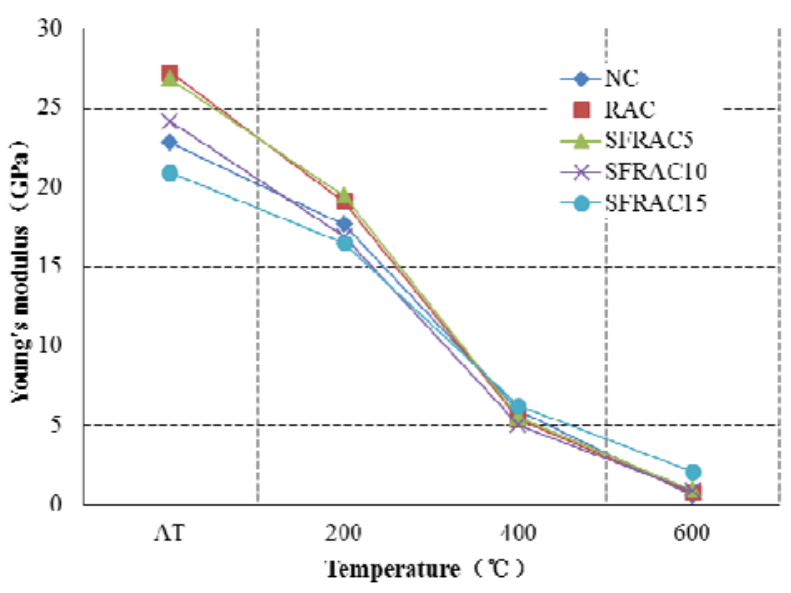

(a) Effect of temperature on Young's modulus

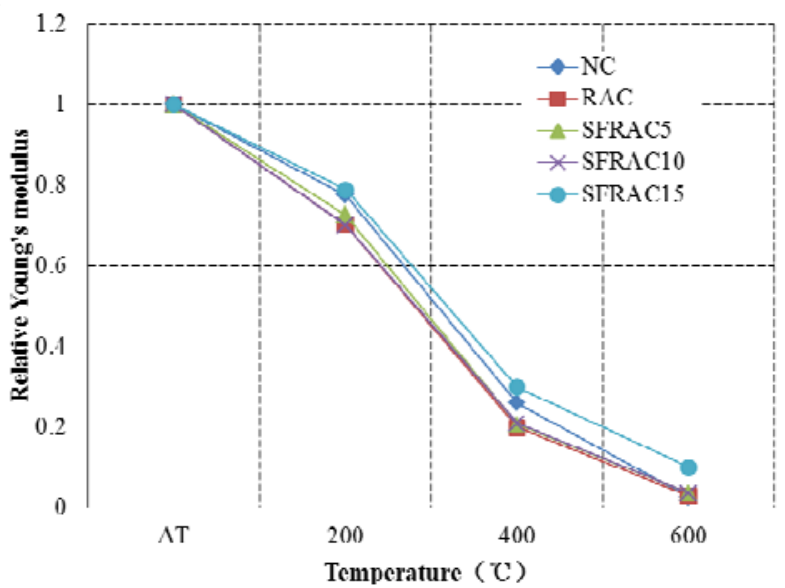

(b) Effect of temperature on relative Young's modulus

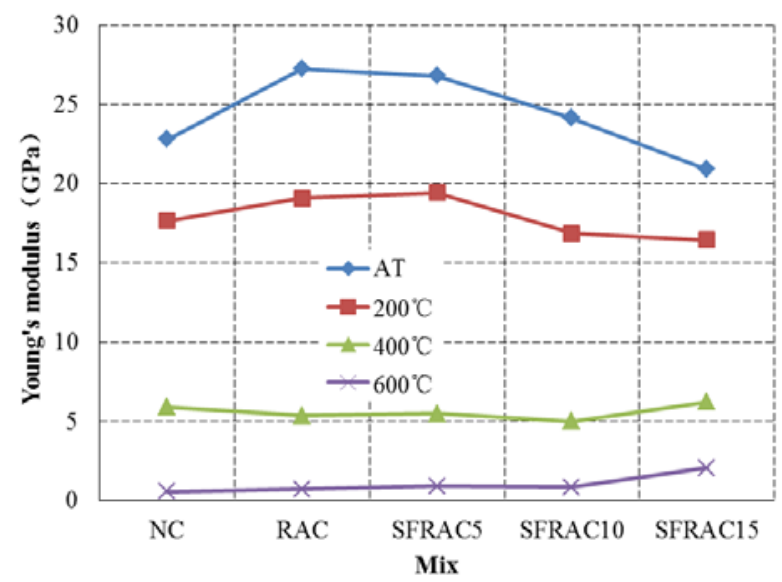

(c) Effect of steel fiber content on Young's modulus

Fig. 12. Effect of temperature on Young's modulus of concrete (AT=Ambient temperature around $\left.25^{\circ} \mathrm{C}\right)$. 


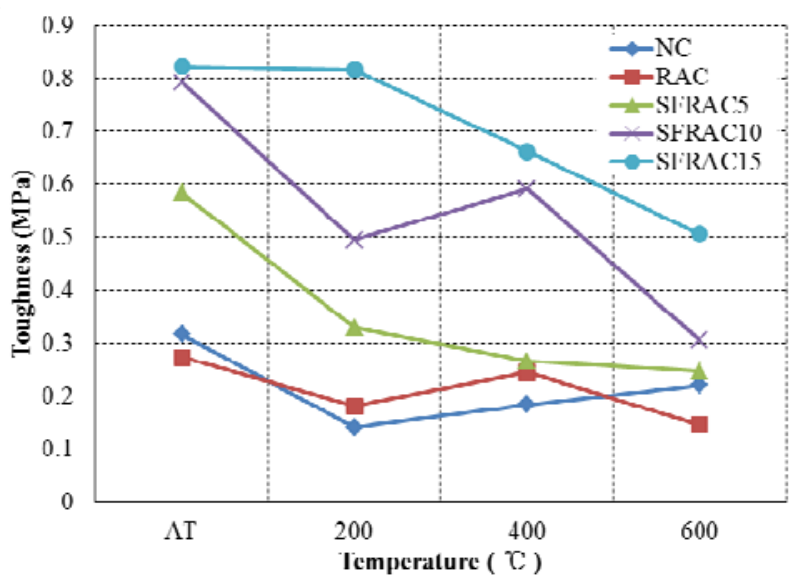

(a) Effect of temperature on toughness

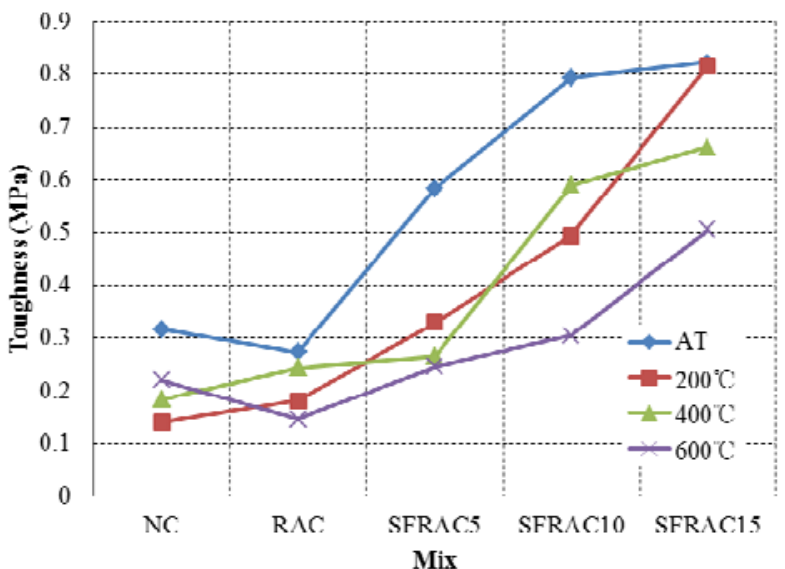

(b) Effect of steel fiber content on toughness

Fig. 13. Toughness of unheated and heated concrete (stress cut-off method) (AT=Ambient temperature around $25^{\circ} \mathrm{C}$ ). 


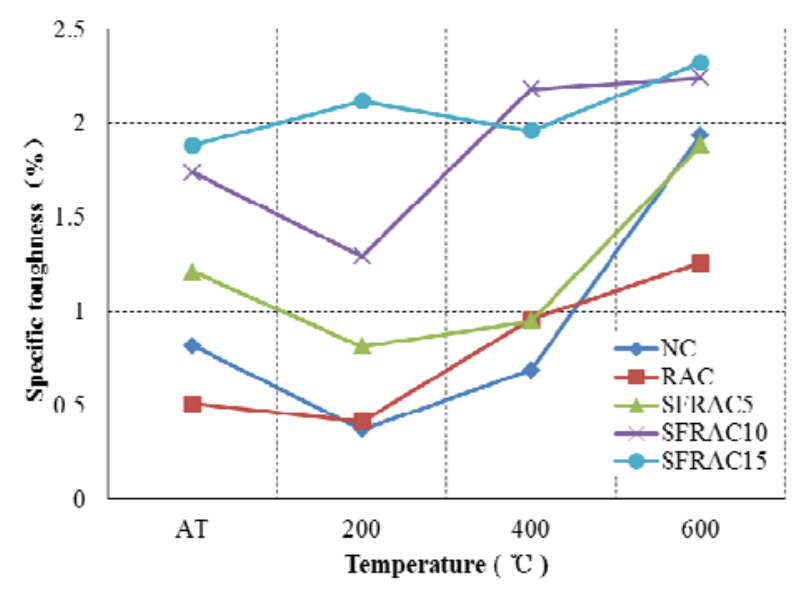

(a) Effect of temperature on specific toughness

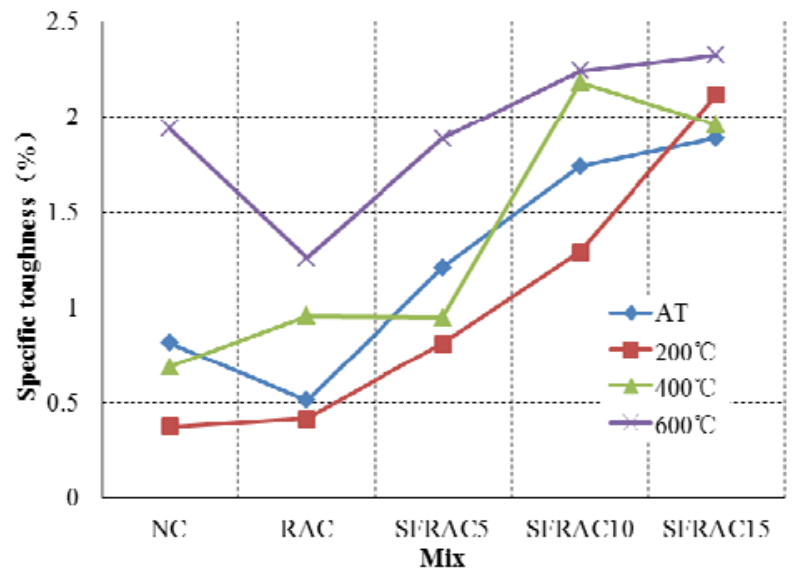

(b) Effect of steel fiber content on specific toughness

Fig. 14. Specific toughness of unheated and heated concrete (stress cut-off method) (AT= Ambient temperature around $25^{\circ} \mathrm{C}$ ). 